\title{
Influence of multidecadal variability on high and low flows: the case of the Seine basin
}

\author{
Rémy Bonnet $^{1}$, Julien Boé ${ }^{1}$, and Florence Habets ${ }^{2,3}$ \\ ${ }^{1}$ CECI, Université de Toulouse, CNRS, Cerfacs, Toulouse, France \\ ${ }^{2}$ UMR 8538, Laboratoire de Géologie de l'Ecole Normale Supérieure, CNRS, PSL, Paris, France \\ ${ }^{3}$ UMR 7619 METIS, Sorbonne Université-Faculté des Sciences, CNRS, Paris, France
}

Correspondence: Rémy Bonnet (remy.bonnet@ipsl.fr)

Received: 19 June 2019 - Discussion started: 16 July 2019

Revised: 27 February 2020 - Accepted: 3 March 2020 - Published: 6 April 2020

\begin{abstract}
The multidecadal hydroclimate variations of the Seine basin since the 1850s are investigated. Given the scarcity of long-term hydrological observations, a hydrometeorological reconstruction is developed based on hydrological modeling and a method that combines the results of a downscaled long-term atmospheric reanalysis and local observations of precipitation and temperature. This method improves previous attempts and provides a realistic representation of daily and monthly river flows. This new hydrometeorological reconstruction, available over more than 150 years while maintaining fine spatial and temporal resolutions, provides a tool to improve our understanding of the multidecadal hydrological variability in the Seine basin, as well as its influence on high and low flows. This long-term reconstruction allows analysis of the strong multidecadal variations of the Seine river flows. The main hydrological mechanisms at the origin of these variations are highlighted. Spring precipitation plays a central role by directly influencing not only the multidecadal variability in spring flows but also soil moisture and groundwater recharge, which then regulate summer river flows. These multidecadal hydroclimate variations in the Seine basin are driven by anomalies in large-scale atmospheric circulation, which themselves appear to be influenced by sea surface temperature anomalies over the North Atlantic and the North Pacific. The multidecadal hydroclimate variations also influence high and low flows over the last 150 years. The analysis of two particularly severe historical droughts, the 1921 and the 1949 events, illustrates how long-term hydroclimate variations may impact short-term drought events, particularly through groundwater-river exchanges. The multidecadal hydroclimate variations described
\end{abstract}

in this study, probably of internal origin, could play an important role in the evolution of water resources in the Seine basin in the coming decades. It is therefore essential to take the associated uncertainties into account in future projections.

\section{Introduction}

Future impacts of climate change on the hydrological cycle could have major socioeconomic consequences (Pachauri et al., 2014). In France, important hydrological changes are expected at the end of the 21 st century in response to global warming, for example a strong general reduction of river flows in summer (Dayon et al., 2018). To develop robust adaptation strategies, an accurate assessment of the uncertainties in impact projections is crucial.

Internal climate variability is a major source of uncertainties in future projections, especially over the coming decades (Deser et al., 2012) and for precipitation (Hawkins and Sutton, 2009; Hingray and Saïd, 2014; Terray and Boé, 2013). Efforts to better evaluate the capacity of climate and/or hydrological models to correctly reproduce hydroclimate variability are therefore necessary, to ensure that the uncertainties in impact projections are correctly estimated. As a first and mandatory step, it is necessary to better characterize and understand hydrological variations in the observations.

A large body of work has dealt with river flow variability over Europe. At interannual timescales, the large-scale atmospheric circulation over the North Atlantic plays a major role in hydrological variations over Europe (Kingston et al., 2006b, a; Bouwer et al., 2008; Steirou et al., 2017). The 
North Atlantic Oscillation (NAO; Cassou et al., 2004; Hurrell and Deser, 2009) in particular is known to influence river flows over Europe, mainly in winter (Kingston et al., 2006b, a; Bouwer et al., 2008; Steirou et al., 2017).

Regarding the uncertainties in impact projections due to internal variability, variations at longer timescales, i.e., at decadal and multidecadal timescales, are more important than interannual variations, as they may modulate the hydroclimate state over several decades, i.e., at climate timescales. They may temporarily reinforce or reduce, or even reverse, the long-term impacts of climate change. Sutton and Dong (2012) have shown that over the 20th century the Atlantic Multidecadal Variability (AMV; Schlesinger and Ramankutty, 1994; Kerr, 2000; Deser et al., 2010; Cassou et al., 2018) - the main mode of decadal to multidecadal variability of the North Atlantic, characterized by basin-wide variations of sea surface temperatures (SSTs) - impacted the European climate through changes in large-scale atmospheric circulation. The positive phases of the AMV tend to reduce precipitation in spring over France. Recent studies have highlighted the existence of strong multidecadal variations in river flows over France (Boé and Habets, 2014; Bonnet et al., 2017). These variations, which can reach up to $40 \%$ of the longterm average, are especially important in spring and are consistent with the negative anomalies in spring precipitation associated with the AMV noted by Sutton and Dong (2012). The river flow variations over France, however, seem to lag the AMV (Boé and Habets, 2014). Consistently, large multidecadal variations have also been observed on a glacier in the French Pyrenees and are likely associated with the AMV (Marti et al., 2014). These multidecadal hydrological variations seem to modulate secular trends in river flows (Dieppois et al., 2016).

Additionally, the AMV could influence extreme hydrological events. Willems (2013) notes the existence of multidecadal variations in extreme precipitation and river flows over Europe, including France, attributed to changes in atmospheric circulation likely driven by the AMV. A recent study by Hodgkins et al. (2017) shows a significant positive influence of the AMV on floods over Europe. A positive relation has also been found between the AMV and heavy precipitation over Europe in all seasons (Casanueva Vicente et al., 2014). The role of warm Atlantic sea surface temperature as a provider of moisture has been put forward to explain this link. Based on the current literature, a competition may therefore exist between the AMV-driven changes in large-scale circulation, which may lead to increases or decreases in precipitation and/or extreme precipitation over Europe depending on the region and the season, and the increase in atmospheric moisture associated with the warmer SSTs of positive AMV phases. Regarding droughts, Giuntoli et al. (2013) show a statistical link between their severity for some French rivers and North Atlantic SSTs during the second half of the 20th century, which are both impacted by internal variability and anthropogenic forcings.
Climate and hydrological observations before the 20th century are rare. As a consequence, the studies discussed previously are very often limited to the 20th century or less, which represents a very short period upon which to base characterization of decadal and multidecadal variability. The sampling uncertainties are indeed very large when statistics of multidecadal variations are calculated over barely more than 100 years and non-stationarity may exist (Qasmi et al., 2017). Additionally, the climate of the 20th century, especially after 1950 , is strongly influenced by external forcings (Bindoff et al., 2013), such as greenhouse gases or anthropogenic aerosols, which may also influence the hydrological cycle over Europe (e.g., Boé, 2016). It is therefore difficult to disentangle the respective roles of external forcings and internal variability in the decadal to multidecadal climate variations of the 20th century, and consequently to understand the responsible mechanisms. The shortness of the observational record has been recognized as a major challenge, as has the need to go further back in the past using innovative new approaches (e.g., Cassou et al., 2018).

Long-term observations of river flows are rare, with very few stations starting before 1900 for example, and they may suffer from non-climatic anthropogenic influences as well as temporal inhomogeneities. Importantly, the other variables of the continental hydrological cycle - such as evapotranspiration, soil moisture or snow - are virtually not observed on such long timescales, which makes it very difficult to understand the hydrological mechanisms at play.

To move forward, long-term hydrometeorological reconstructions based on hydrological modeling have been developed (e.g., Kuentz et al., 2015; Caillouet et al., 2016). Due to the scarcity of meteorological observations in the early 20th century (Minvielle et al., 2015), the meteorological forcing needed for hydrological modeling must first be reconstructed. The recent release of long-term global atmospheric reanalyses (e.g., Twentieth Century Reanalysis (20CR; Compo et al., 2011) from the National Oceanic and Atmospheric Administration (NOAA)) opens great opportunities in that context. Statistical downscaling methods, typically used in climate change impact studies, can be applied to derive the high-resolution meteorological forcing necessary for hydrological modeling from these global atmospheric reanalyses, as in Caillouet et al. (2016). This approach presents two main limitations. First, the quality of the reconstruction depends on the quality of the reanalyses. As the density of assimilated observations (e.g., surface pressure in NOAA 20CR; Compo et al., 2011) strongly evolves over time, potentially unrealistic trends and/or low-frequency variations may exist (Krueger et al., 2013; Oliver, 2016; Bonnet et al., 2017). Second, this approach does not take advantage of the longterm local meteorological observations that may exist.

Given these limitations, following the same general idea as Kuentz et al. (2015), Bonnet et al. (2017) presented a new hybrid method that combines available long-term monthly observations of precipitation and temperature with the results of 


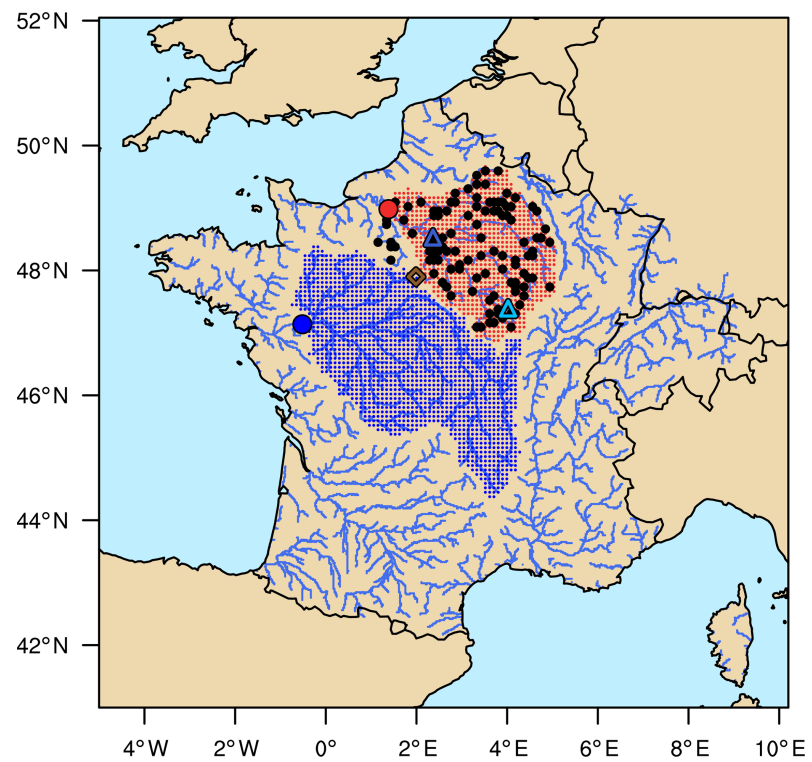

Figure 1. Location of the Seine catchment (red area) corresponding to the Seine at Poses station, considered as the outlet (red dot), and of the Loire catchment (blue area) for the Loire at Montjeansur-Loire station (blue dot). Location of hydrometric stations both observed and simulated (black circles), and of the two long-term river flows observations available: the Paris Austerlitz station (dark blue triangle) and the Aisy-sur-Armançon station (light blue triangle). Location of the long-term piezometric level series at Toury (brown rhombus).

a statistical downscaling method applied to long-term atmospheric reanalyses. Compared to standard dynamical or statistical downscaling methods that only use large-scale information and do not take advantage of local observations (e.g., temperature and precipitation), a more realistic representation of local hydroclimate variations can be obtained (Bonnet et al., 2017).

In this study, we build upon the methodology developed in Bonnet et al. (2017) and target two main improvements. First, the reconstruction is extended back in the past in order to assess more robustly the multidecadal variations. Given data availability, the reconstruction of Bonnet et al. (2017) begins in 1900. Focusing on the Seine basin (Fig. 1), one of the main French river basins, we are able to extend the reconstruction back to the 1850s. The interest of this basin is the existence of long observational series of different variables contributing to the hydrological cycle, which are useful for developing and evaluating the reconstructions. Additionally, we improve the method to better capture daily variability, in order to have a finer reconstruction of high and low flows. This allows us to study whether high and low flows are influenced by multidecadal variations, which may have important socioeconomic impacts.

This study has three main objectives: (i) to characterize the hydroclimate variations of the Seine basin since the 1850s, (ii) to study the hydrological and climatic mechanisms that cause these variations and (iii) to investigate the influence of these multidecadal variations on low and high flows.

The data, models and methods used are presented in Sect. 2. The development of the hydrometeorological reconstruction is described in Sect. 3. The hydrometeorological reconstruction is then evaluated against observations in Sect. 4. From this reconstruction, the hydroclimate variations of the Seine basin are characterized in Sect. 5, and the hydrological mechanisms associated with these variations are analyzed. In Sect. 6, the climate mechanisms underlying the hydrological multidecadal variations over the Seine basin are analyzed. The link between these multidecadal variations and high and low flows is then explored in Sect. 7. Two historical droughts are then analyzed in detail. Finally, the main limitations of this study are discussed in Sect. 8, and conclusions and perspectives are drawn in Sect. 9.

\section{Data, models and methods}

\subsection{Observations}

Daily river flows at 136 gauging stations over the Seine basin (Fig. 1) from the national HYDRO database (http: //www.hydro.eaufrance.fr, last access: 27 February 2020) are used for the evaluation of the reconstruction. These river flow series, of variable lengths, all start before 1970 and may contain missing values. Some of the stations are very likely influenced by human activities (e.g., dams or water abstraction). These series are not homogenized, and therefore not necessarily free of measurement artifacts. The interpretation of observed variations at any single station must therefore be carried out carefully. Two long-term series, starting before 1900, are also available and used for the analysis of the link between extreme events and multidecadal hydroclimate variations, one at Paris Austerlitz on the Seine river (catchment area: $43800 \mathrm{~km}^{2}$ ) and one at Aisy-sur-Armançon on the Armançon river (catchment area: $1350 \mathrm{~km}^{2}$ ) (Fig. 1). A long series of piezometric levels is also used to evaluate the hydrological reconstruction (Fig. 1). The Beauce groundwater table at Toury, which has been monitored since the 1870 s, is one of the few long piezometric measuring stations in France (Nicolas et al., 2013). These observations, which are used in particular to evaluate the hydrometeorological reconstruction developed in this study, are independent of it.

Different meteorological observations are used for the reconstruction. Monthly homogenized series of temperature and precipitation over the Seine basin from the Série Mensuelle de Réference (SMR, monthly series of reference) data set, developed by Météo-France (Moisselin et al., 2002), are used. Seventeen stations are available for precipitation and four for temperature, from 1885 to 2005. A long series of monthly precipitation at Paris (Slonosky, 2002), available since the late 17th century, is also used for the periods not 
covered by the SMR observations series at Paris, from 1852 to 1885 and from 2005 to 2008 . Daily temperature and precipitation series from the Série Quotidienne de Réference (SQR, daily series of reference) data set between 1885 and 2003 are also used (Moisselin and Dubuisson, 2006). They are not homogenized. The number of stations varies greatly in time, from two to around 60 for precipitation and from one to seven for temperature.

\subsection{The SAFRAN-SURFEX-Aqui-FR hydrometeorological system}

The hydrological reconstruction is based on the French Aqui-FR hydrogeological modeling platform (Vergnes et al., 2020). Aqui-FR couples several hydrogeological models over France to the SURFEX land surface model (Masson et al., 2013). The ISBA (Interactions between Soil, Biosphere, and Atmosphere; Noilhan and Planton, 1989) component of the SURFEX modular land surface model, used for example in the French CNRM-CM5 coupled climate model (Voldoire et al., 2013), computes the water and energy exchanges at the interface between the soil, the vegetation and the atmosphere. In this study, version 8.1 of SURFEX is used, with the multilayer version of ISBA (Decharme et al., 2013). The surface runoff and the drainage simulated by SURFEX are then routed through the multilayer aquifers and rivers of the Seine basin by Aqui-FR.

Over the Seine basin, the EauDyssée hydrogeological model (Saleh et al., 2011) is used on the Aqui-FR platform. This hydrogeological model is an improved version of the MODCOU hydrogeological model used in Bonnet et al. (2017). Unlike MODCOU, the EauDyssée hydrogeological model implemented in Aqui-FR includes the simulation of river water levels, allowing for a better estimation of water exchanges between groundwater and rivers (Saleh et al., 2011). The exchanges between groundwater and rivers are computed daily based on the gradient head between the aquifer and the river, and a transfer coefficient that accounts for the river bed characteristic (see Vergnes and Habets, 2018, for details. The water transfers in the unsaturated zone are improved (Philippe et al., 2011), which may be important considering that the unsaturated zone can reach $60 \mathrm{~m}$ in the Seine basin, implying a delay in the groundwater recharge. Finally, Aqui-FR uses a six-layer representation of the aquifers (Viennot et al., 2009; http://www.geosciences. ens.fr/aqui-fr/\#_Documents, last access: 27 February 2020), compared to the three layers used in MODCOU (Rousset et al., 2004). Aqui-FR has therefore a more realistic representation of groundwater and water exchanges between groundwater and rivers compared to the version of MODCOU used in Bonnet et al. (2017). Water abstractions can be taken into account in Aqui-FR. However, in order to focus only on climate influences, the reconstruction developed in this study does not take water abstractions into account, which may explain some of the differences between the reconstruction and observations. In any case, water abstractions of the late 19th century are not known.

The SAFRAN analysis, based on thousands of observation stations collected by Météo-France and an optimal interpolation algorithm, provides the seven atmospheric variables necessary to force the SURFEX-Aqui-FR system (liquid and solid precipitation, incoming longwave and shortwave radiation fluxes, $10 \mathrm{~m}$ wind speed, $2 \mathrm{~m}$ specific humidity and temperature) at an hourly time step on an $8 \mathrm{~km}$ grid from 1958 to present. The SAFRAN analysis is described and evaluated in Quintana-Segui et al. (2008) and Vidal et al. (2010).

A simulation based on the SAFRAN-SURFEX-Aqui-FR system is available over the period 1958-present. This socalled reference simulation is used for the evaluation of the hydrometeorological reconstruction of their common period. As they share the same hydrological model, potential differences between the reconstruction and the reference simulation only depend on the quality of the reconstructed meteorological forcing.

\subsection{Method}

In order to extract the multidecadal variations from interannual series, a Lanczos low-pass filter (Duchon, 1979) with a cutoff frequency of $1 / 30$ years and 31 weights is applied. No padding at the ends of the series is applied: the first 15 years and the last 15 years of the unfiltered series are considered as missing values in the filtered series. As this study is focused on multidecadal variations, long-term trends are first removed for most of the analyses presented in this study. As it is very unlikely for the trend to be linear over the long periods analyzed in the paper, non-linear trends are computed using an ensemble empirical mode decomposition algorithm (EEMD; Wu and Huang, 2009). This algorithm decomposes a series into a sum of signals that characterize the different temporal variability scales that compose this series. The algorithm also extracts a non-linear trend. This method is adaptive to the signal studied and non-parametric.

In order to avoid an artificial skill induced by the annual cycle when calculating daily or monthly correlations between the observations and the reconstruction, the series are deseasonalized. For daily series, a centered running average of $31 \mathrm{~d}$ is applied first to limit the noise in the computed annual cycle. Then, the climatological average is calculated for each day of the year. For monthly series, the annual cycle is simply calculated as the climatological average of each month.

In this paper, winter means December-January-February (DJF), spring means March-April-May (MAM), summer means June-July-August (JJA) and fall means SeptemberOctober-November (SON). 


\section{Development of the Seine hydrometeorological reconstruction}

A new hydrological reconstruction, based on hydrological modeling, is developed over the Seine basin, improving the method presented in Bonnet et al. (2017), with two main objectives: (i) to extend the study period to the $1850 \mathrm{~s}$, in order to characterize more robustly multidecadal hydroclimate variations, and (ii) to improve the representation of river flows, particularly at the daily timescale, in order to obtain a better representation of high and low flows and study their multidecadal variations. Fig. 2 describes the main steps of the method developed in the present study and highlights the improvements over the one used in Bonnet et al. (2017).

To obtain the meteorological forcing necessary for hydrological modeling, the main idea of the Bonnet et al. (2017) method is to use the analog method (Lorenz, 1969), a stochastic statistical downscaling method, to downscale a long-term atmospheric reanalysis (e.g., NOAA 20CR) and produce an ensemble of trajectories of precipitation and temperature over France (Step 1, Fig. 2). Then, local long-term monthly precipitation and temperature observations are used to select the best trajectory (Step 3, Fig. 2). In the present study, we add a daily constraint to this method in order to improve the simulation of daily river flows (Step 2, Fig. 2).

To extend the study period, the long-term NOAA 20CRv2c atmospheric reanalysis (Compo et al., 2011), which begins in 1851, is used. This reanalysis is based on a global atmospheric model, using observed sea ice and SST as boundary conditions together with the assimilation of surface and sea level pressure observations. The SSTs used are SODAsi.2 (Simple Ocean Data Assimilation system) (Giese et al., 2016) for latitudes between $60^{\circ} \mathrm{N}$ and $60^{\circ} \mathrm{S}$ and COBE-SST2 (Centennial In Situ Observation Based Estimates of the Variability of SST and Marine Meteorological Variables) (Hirahara et al., 2017) for the highest latitudes. Fifty-six members, sampling the reanalysis uncertainties, are available.

\subsection{Step 1: statistical downscaling}

The analog method is based on the hypothesis that $2 \mathrm{~d}$ with similar large-scale atmospheric states (e.g., large-scale atmospheric circulation over the North Atlantic) are characterized by similar local weather conditions. In its most basic form, for each day $D$ of the reanalysis, the day $D_{\text {a }}$ (the socalled analog day) with the closest large-scale atmospheric state is searched for within the learning period, defined as the common period between the reanalysis and the observational database with the local variables necessary for hydrological modeling, for example the SAFRAN analysis here. The local variables of interest of the day $D_{\mathrm{a}}$ in the observational database are selected as an estimate of the local weather conditions for the day $D$. To quantify the similarity between large-scale atmospheric states, four predictors are used in the present work: precipitation, surface temperature, sea level pressure and specific humidity at $850 \mathrm{hPa}$. The Euclidean distance is computed for each predictor except sea level pressure, for which the Teweles and Wobus score (Teweles Jr and Wobus, 1954; Obled et al., 2002) is calculated. The distances and the score are then combined after standardization to give the same weight to each predictor. Two domains of analogy are used. The domain for sea level pressure is delimited by the following coordinates: $44^{\circ} \mathrm{N}, 56^{\circ} \mathrm{N},-11^{\circ} \mathrm{E}$ and $16^{\circ} \mathrm{E}$. The domain for the three other predictors is defined by $46^{\circ} \mathrm{N}$, $51^{\circ} \mathrm{N},-2^{\circ} \mathrm{E}$ and $7^{\circ} \mathrm{E}$.

In contrast to Bonnet et al. (2017), where only one member of the long-term reanalysis is downscaled ( $\mathrm{NR}=1$, Fig. 2 ), here we statistically downscale the 56 members of NOAA $20 \mathrm{CRv} 2 \mathrm{c}(\mathrm{NR}=56$; Fig. 2). This leads, for each day $D$ of the reconstruction period, to a much larger pool of potential analog days, which allows us to add a new step: a daily constraint by local observations (Step 2, Fig. 2). The objective of this new step is to obtain a better representation of daily variations of the meteorological forcing.

\subsection{Step 2: daily constraint}

Instead of searching only for the best analog day $D_{\mathrm{a}}$ for each day $D$ of the reconstruction period (1852-2008), the $N$ best analog days $D_{\mathrm{a} 1}, D_{\mathrm{a} 2}, \ldots D_{\mathrm{a} N}$ in the learning period (19582008 , limited by the availability of SAFRAN) - i.e., those with the most similar large-scale atmospheric states - are searched for. In the present method, $N=50$. As the $56 \mathrm{mem}$ bers of NOAA 20CRv2c are downscaled, in the end 2800 potential analog days are obtained for each day $D$ of the reconstruction period (with potentially similar analog days for the different members). As each analog day corresponds to a day of the learning period, the corresponding daily maps of precipitation $\operatorname{Pr}\left(D_{\mathrm{a} 1}\right), \operatorname{Pr}\left(D_{\mathrm{a} 2}\right), \ldots \operatorname{Pr}\left(D_{\mathrm{a} N}\right)$ and temperature Tas $\left(D_{\mathrm{a} 1}\right), \operatorname{Tas}\left(D_{\mathrm{a} 2}\right), \ldots \operatorname{Tas}\left(D_{\mathrm{a} N}\right)$ from SAFRAN are selected and compared to the daily station observations (SQR; see Sect. 2.1) after regridding. Regridding consists in selecting the SAFRAN grid point closest to each observation station over the Seine basin. Note that the number of stations varies over the period 1852-2008. The comparison is therefore done each day of the reconstruction based on the available stations.

The daily comparison is based on the following approach.

i. The average daily bias in mean precipitation averaged over the Seine basin is calculated for the 2800 analog days, and the 60 analog days with the lowest bias are selected.

ii. The spatial root mean square errors (RMSEs) for the 60 analog days are calculated for temperature. For precipitation, the error to the cubic power rather than to the square power is used, in order to give more weight to strong values of precipitation, and the absolute value is used. 


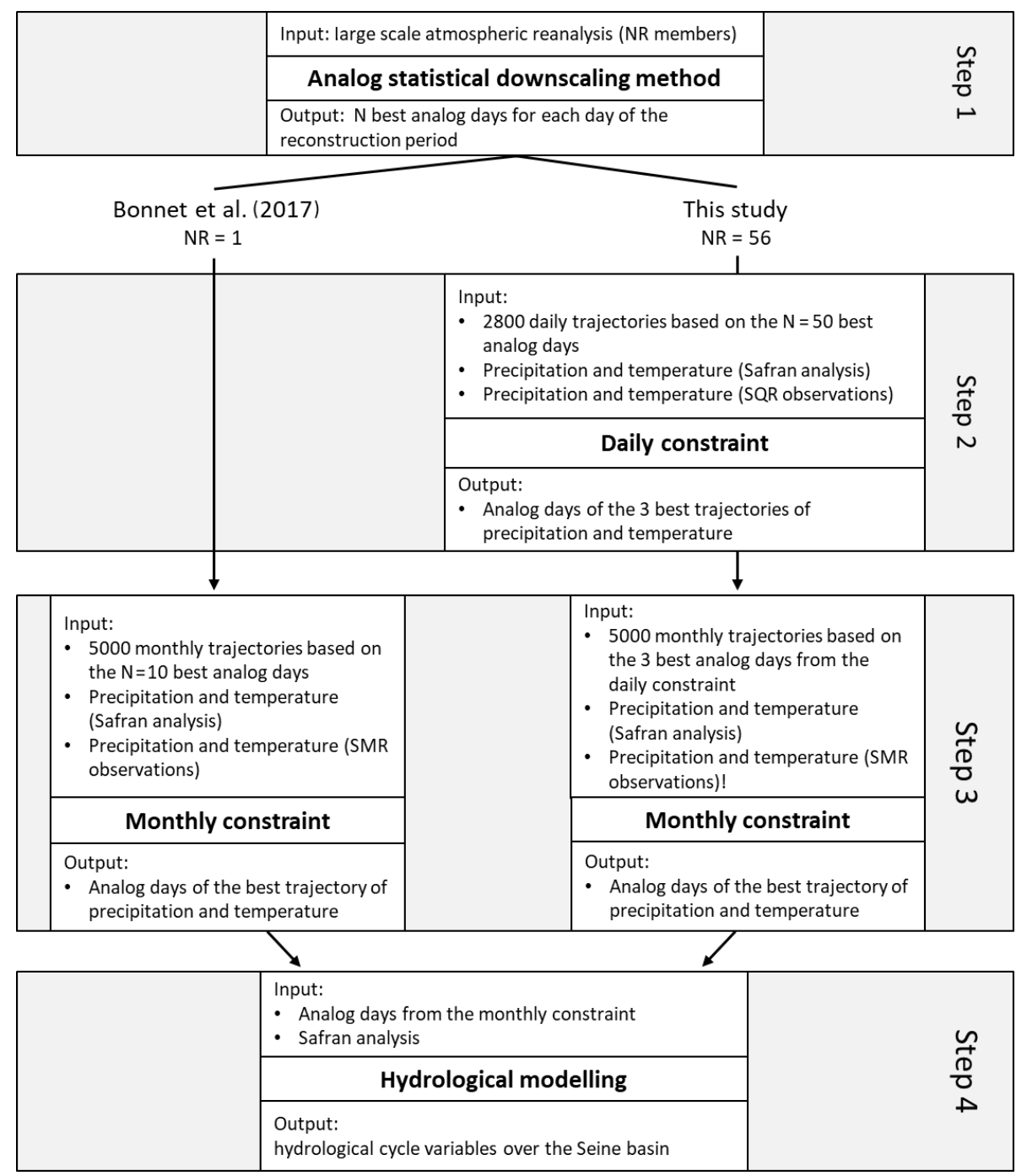

Figure 2. Schematic representation of (on the right) the method used to obtain the hydrological reconstruction in this study and (on the left) the method used in Bonnet et al. (2017), which does not include a daily constraint (Step 2).

iii. The daily series of spatial errors obtained for precipitation and temperature are then standardized based on the statistics of the entire period and added, with a weight of 1 for precipitation and 0.5 for temperature.

iv. Finally, from each day of the reconstruction period, the 3 best analog days (out of 60), i.e., those with the smallest errors compared to observations, are selected.

\subsection{Step 3: monthly constraint}

Based on the 3 analog days selected thanks to the daily constraint, multiple trajectories of precipitation and temperature over the Seine basin are then created by repeatedly selecting randomly 1 of the 3 analog days for each day $D$ of the reconstruction. In practice, 5000 trajectories are created (Step 3, Fig. 2). The monthly averages of precipitation (temperature) for these trajectories are computed. From the three different maps of precipitation (temperature) over the Seine basin obtained with the daily constraint for each day $D$ of the reanalysis, 5000 different monthly maps of precipitation (temperature) are obtained with this procedure.

For each month of the reconstruction, the 5000 maps of precipitation (temperature) obtained on the SAFRAN grid are regridded and compared to the actual observed precipitation (temperature) map, using the long-term homogenized precipitation (temperature) series over France (see Sect. 2) as a reference. The spatial RMSEs are computed for temperature and precipitation. The sum of the RMSEs corresponding to precipitation and to temperature is then computed after the temporal standardization of the series of RMSEs in order to give the same weight to each variable. In the end, for each month of the reconstruction, the daily series of analog days among the sample of 5000 that leads to the lowest sum of 
RMSEs is selected. The term "monthly constraint" used in this study refers to this last step (Step 3 in Fig. 2).

The interest in using a monthly constraint after the daily constraint is that monthly data are homogenized, contrary to daily data (Sect. 2), and therefore it allows for a better representation of low-frequency variations.

\subsection{Discussion}

The method described above benefits from the advantages of the analog statistical downscaling method. Thanks to the analog days, all the meteorological variables from SAFRAN necessary to force the SURFEX-Aqui-FR hydrological model are obtained. The spatial and inter-variable consistencies are maintained after this procedure, because for each day of the reconstruction the entire map of precipitation (and temperature, humidity etc.) over France from SAFRAN is selected based on a single analog day. Compared to a basic statistical downscaling method, our method additionally takes into account local observations in the downscaling process and not simply large-scale information. The use of local observations allows for a more accurate reconstruction, as shown in Bonnet et al. (2017). Note that the temporal consistency of the meteorological forcing is ensured by the temporal consistency both of the predictors and of the local observations.

Multiple tests have been conducted to setup the different ad hoc aspects of the method, trying to obtain the best overall hydrometeorological reconstruction. These tests concern, for example, the best combination of weights given to precipitation and temperature errors at Step 2 or the number of analogs selected at each step. For example, selecting only the 3 best analog days at the end of Step 2 leads to the best overall performance in capturing daily and monthly variations. Using more analog days may allow for a better representation of monthly variations but degrades the representation of daily variations.

To sum up, the hydrometeorological reconstruction developed over the Seine basin is constrained on a daily basis over the period 1885-2003 by observations of precipitation and temperature (SQR), on a monthly basis over the period 1885-2005 by homogenized observations of precipitation and temperature (SMR), and over the periods 18521884 and 2005-2008 by the monthly series of precipitation at Paris (Slonosky, 2002) (see Sect. 2.1 for more details). The results, especially at the daily timescale, therefore have to be interpreted with more caution over the period constrained only by the monthly series of precipitation.

During the development of the reconstruction, mean climatological biases were found for reconstructed precipitation and incoming shortwave radiation in comparison to SAFRAN over their common period. These mean climatological biases are corrected before hydrological modeling by calculating for each season of the study period the climatological bias using SAFRAN as a reference. Then, for each season (e.g., winter 1852 , spring 1852 , summer 1852 ...), the bias is corrected proportionally at an hourly time step.

The meteorological forcing obtained for the period 1852 2008 with the approach described in this section is finally used to force the SURFEX-Aqui-FR hydrogeological model to obtain the hydrological reconstruction over the Seine basin (Step 4, Fig. 2).

\section{Evaluation of the Seine reconstruction}

\subsection{Mean river flows}

First, the temporal correlations between observed river flows and river flows from the Bonnet et al. (2017) reconstruction, the present reconstruction and the reference simulation are calculated at the daily and monthly timescale for the period 1958-2005 at the 136 gauging stations available over the Seine basin (Sect. 2.1). The median of these temporal correlations is, respectively, 0.7 and 0.97 for daily and monthly timescales (Fig. 3). The daily and monthly river flow variations are therefore correctly captured in the Seine reconstruction. At the monthly timescale, the river flow variability is reproduced almost as effectively as in the reference simulation. For most gauging stations, the representation of daily and monthly river flows is improved in the Seine reconstruction compared to the reconstruction developed over France by Bonnet et al. (2017). Some low correlations are still seen for a few stations (Fig. 3). These stations are identical in the reconstructions and in the reference simulation, showing that this issue is not due to the reconstructed meteorological forcing. Non-climatic anthropogenic influences (e.g., dams, pumping or land use changes) that are not taken into account by the hydrological model or measurement artifacts might be responsible for these lower correlations. Alternatively, they may be due to the hydrological model, especially since these lower correlations are seen for small catchments (not shown), generally less well simulated by the hydrological system.

To evaluate the reconstruction over a longer period, river flows from the reconstruction are compared to observations at the two stations with long-term data on the catchment: the Seine at Paris and the Armançon at Aisy-sur-Armançon (Sect. 2) (Fig. 4a and b). The reconstruction correctly reproduces the interannual variability at both stations, although differences in terms of amplitude are seen. For example, river flows in 1910, influenced by an exceptional flood, are underestimated at Paris. They are more correctly reproduced at Aisy-sur-Armançon. The multidecadal variability of observed flows is also quite well reproduced by the reconstruction (Fig. 4c and d), even if the anomalies for the Seine at Paris tend to be underestimated at the beginning of the 20th century and overestimated at the end (Fig. 4c). Differences in long-term trends, with a stronger negative trend in the observed series compared to the reconstruction (not shown), are probably at the origin of these differences. It is very 

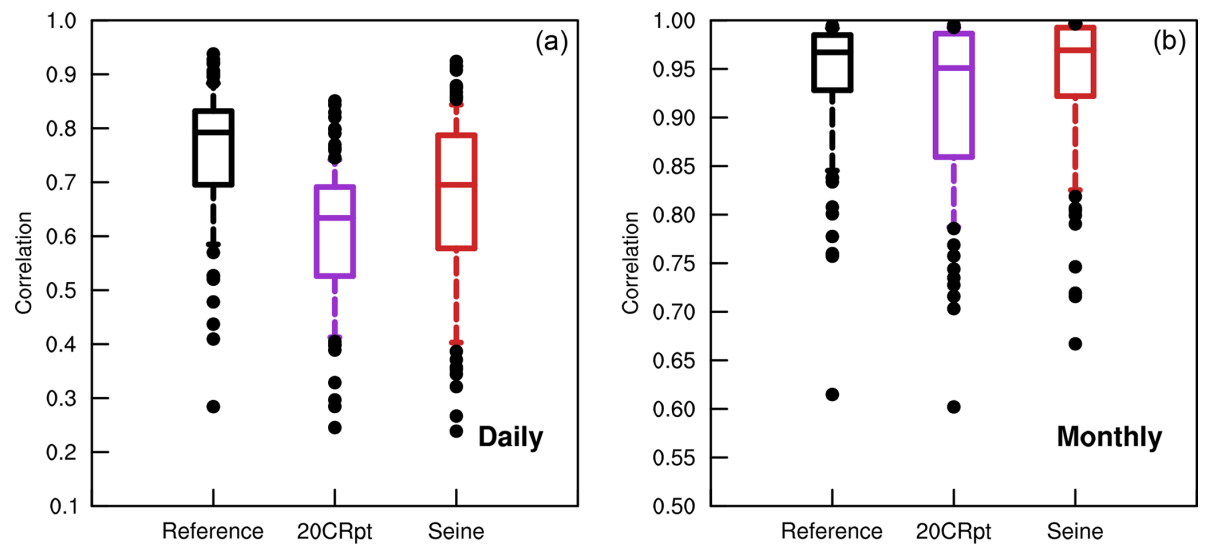

Figure 3. Spatial distribution of the correlations between the 136 river flow observations over the Seine basin at (a) daily and (b) monthly time steps and the (black) reference simulation (SAFRAN-SURFEX-Aqui-FR), (purple) the 20CRpt reconstruction described in Bonnet et al. (2017) and (red) the Seine reconstruction developed in the present study. The correlations are calculated for the period 1958-2005 and the series have been deseasonalized beforehand. The boxplots show the 10th percentile, 25th percentile, median, 75th percentile and 90th percentile. The black dots are the values below and above the 10th and the 90th percentiles, respectively.
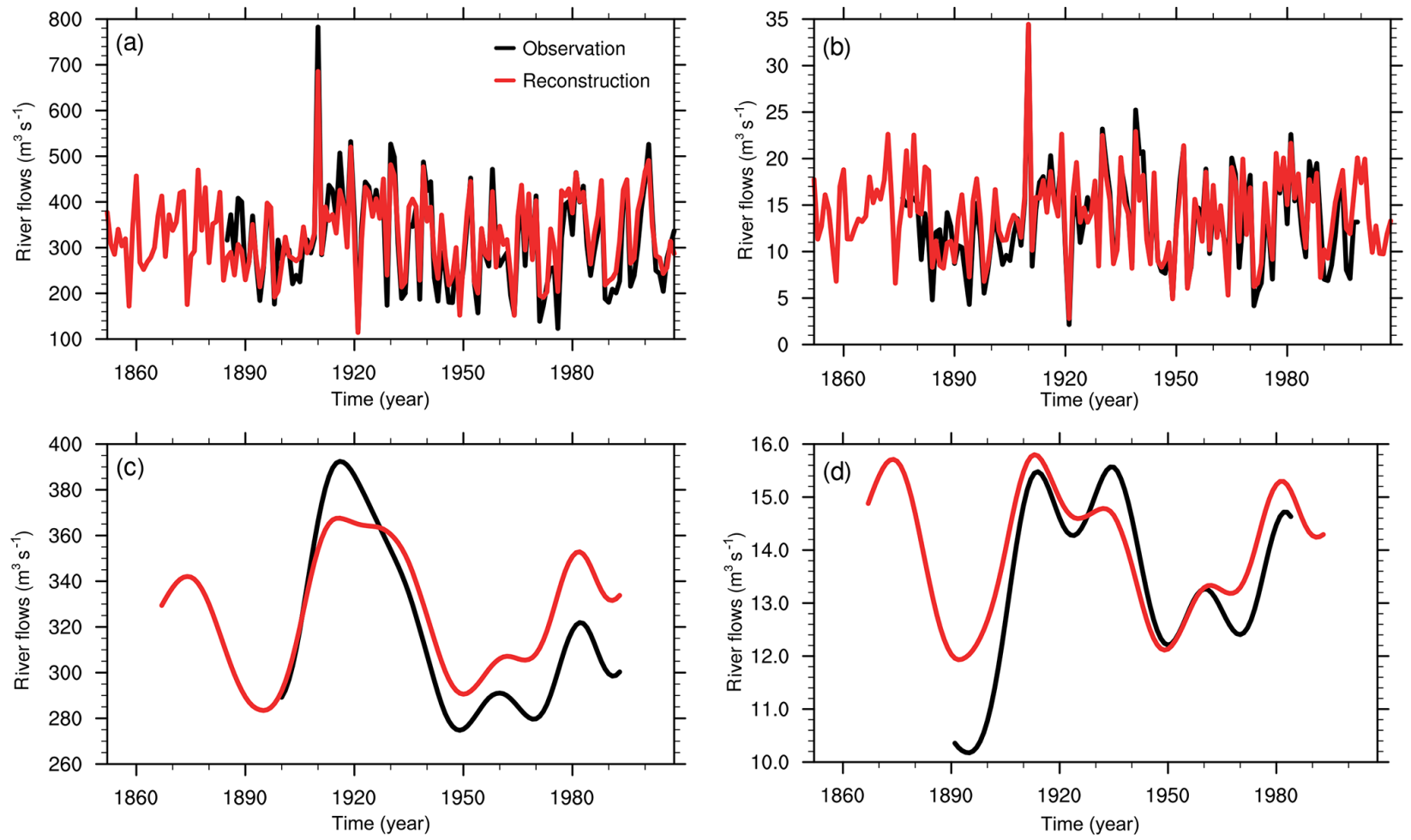

Figure 4. Annual series of river flows for (a) the Seine at Paris and (b) the Armançon at Aisy-sur-Armançon (see Fig. 1). (c, d) Annual low-pass-filtered series of river flows for the same stations as panels (a) and (b). Black: observations. Red: Seine reconstruction.

unlikely that a potentially unrealistic trend has been introduced in hydrological reconstruction by the meteorological forcing developed in Sect. 3, as the reconstructed precipitation and temperature series do not show unrealistic trends (not shown). It is possible that measurement artifacts, or nonclimatic anthropogenic influences, not taken into account in the reconstruction have influenced the long-term variations of observed river flows in that region, which is heavily impacted by human activities. Multidecadal river flow variations at Paris and at Aisy-sur-Armançon are generally in phase. A strong positive multidecadal phase, which corresponds to a succession of years with higher-than-average river flows, is visible around 1920; a negative phase is present around 1890 and 1960. 


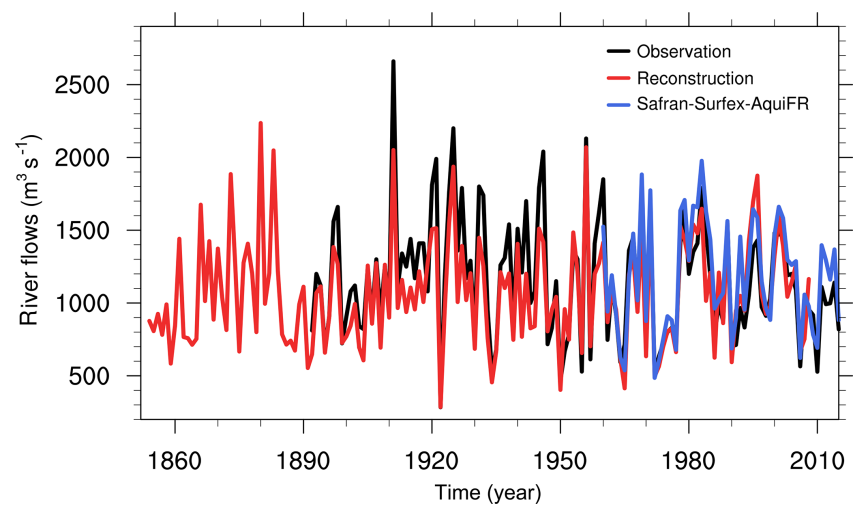

Figure 5. Annual maximum of daily river flows for the Seine at Paris. Black: observations. Red: Seine reconstruction. Blue: reference simulation (SAFRAN-SURFEX-Aqui-FR).

\subsection{Annual maximum daily river flow}

The annual maxima of daily river flows are computed for the Seine reconstruction, the reference simulation and the observations for the Seine at Paris and compared (Fig. 5). The interannual variability of the annual maximum daily river flow of the Seine at Paris is well captured in the Seine reconstruction, with a correlation of 0.88 with the observations of the period 1900-2005 (Fig. 5). The correlation is consistent over time, with a correlation of 0.92 over the period 1900-1960 and of 0.89 over the period 1960-2005. For the later period, the correlation between the reconstruction and the observation is close to the correlation obtained with the reference simulation $(r=0.95)$.

The annual maximum daily river flow is generally underestimated in the reconstruction before the 1960s (Fig. 5). As a result, the magnitude of the exceptional 1910 flood is largely underestimated in the reconstruction, even if this event remains the largest in the reconstruction. The bias is far less pronounced in the reconstruction after 1960 and in the reference simulation, as a result of an apparent decrease in the observed annual maximum. The construction of large reservoirs over the Seine basin upstream from Paris that started in the 1960s, whose objectives include flood control, might be the cause of the observed decrease.

\subsection{Piezometric levels}

In France, long-term observations of piezometric levels (measure of the head of a groundwater table) are very rare. The measurements at the Toury sugar plant, which have monitored the Beauce groundwater table since the beginning of the 20th century, are especially interesting in this context. The Beauce aquifer is a limestone aquifer from the Oligocene, and it is drained by rivers mainly at its borders. The observed piezometric level at Toury shows strong multidecadal variations, with a positive phase around the period 1920-1940, preceded by a negative phase in the early

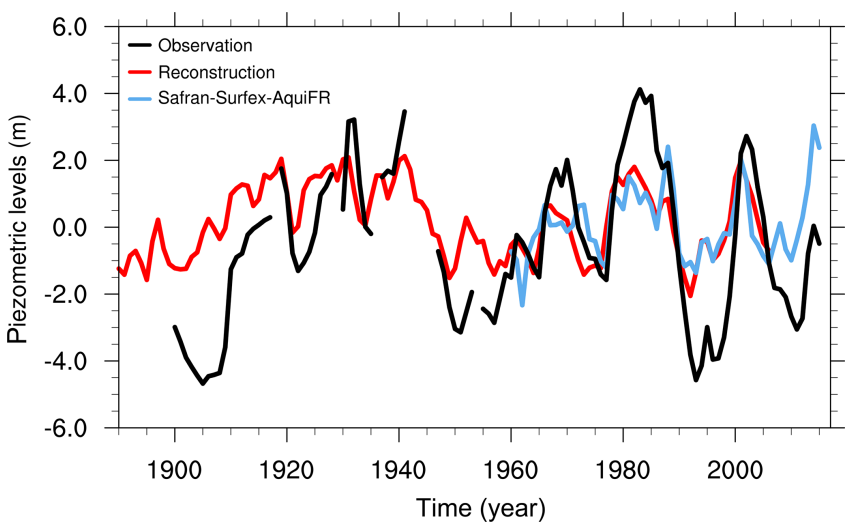

Figure 6. Annual anomalies of the piezometric levels of the Beauce groundwater table at Toury. The reference period is 1960-2005. Black: observations. Red: Seine reconstruction. Blue: reference simulation (SAFRAN-SURFEX-Aqui-FR).

20th century and followed by a negative phase in the 1950s (Fig. 6). Strong decadal peaks are also seen after 1950, consistent with Flipo et al. (2012). The evolution of the Beauce groundwater is generally consistent with that of river flows (Fig. 4) at multidecadal timescales.

The interannual variations of piezometric heads at Toury are quite well reproduced in the reconstruction, with a correlation of 0.74 over the 20th century. The amplitude of these variations is, however, strongly underestimated, by a factor of 2 , both in the reconstruction and in the reference simulation. This might be linked to a coarse representation of the aquifer complexity in Aqui-FR. A partially captive part of the limestone aquifer, which contains lenses of clay, is not represented in the model due to its insufficient resolution. This part of the aquifer amplifies the flow time and, therefore, the memory of the aquifer.

\section{Multidecadal hydroclimate variations in the Seine basin}

\subsection{Characterization}

Low-pass-filtered annual river flows of the Seine at Poses (see location in Fig. 1) from the reconstruction show strong multidecadal variations during the 20th century (Fig. 7), consistent with the observed variations over France described in Boé and Habets (2014).

Major sampling uncertainties exist when dealing with multidecadal variations using the short observational record. Additionally, since the mid-20th century, the climate has been strongly impacted by anthropogenic forcings, making it difficult to disentangle the respective role of internal variability and external forcings in observed hydroclimate variations. Thanks to the extended length of our reconstruction compared to previous works, we show that multidecadal vari- 


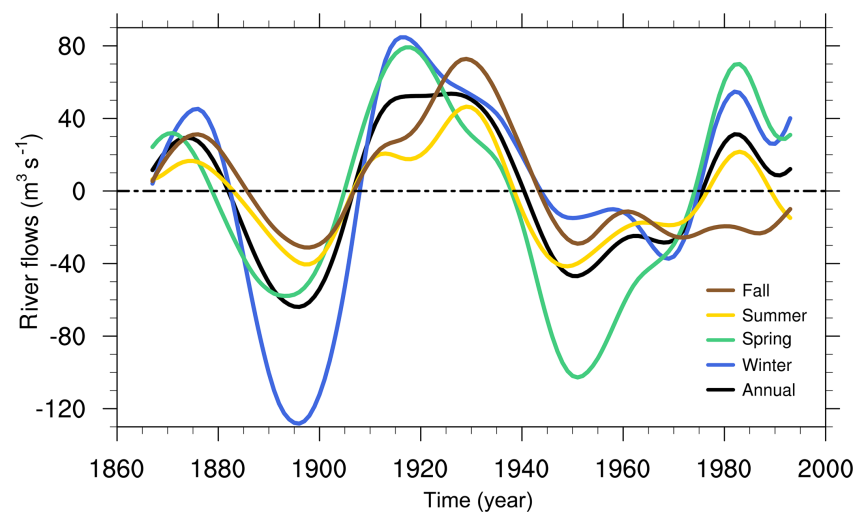

Figure 7. Low-pass-filtered interannual anomalies of the Seine river flows at the Poses station in the reconstruction. Black: annual; blue: winter; green: spring; yellow: summer; and brown: fall. The annual mean over the whole period is $446 \mathrm{~m}^{3} \mathrm{~s}^{-1}$.

ations also exist before the 20th century, with lower-thanaverage river flows around the period 1885-1905 (about $15 \%$ lower than the average of $446 \mathrm{~m}^{3} \mathrm{~s}^{-1}$ for annual river flows). This reinforces our confidence in the reality of the multidecadal hydrological variations in France observed over the 20th century and in the idea that they are at least partly of internal origin. Phased multidecadal variations also exist for the seasonal averages, with the strongest absolute variations seen in spring and winter. Note, however, that, as climatological river flows are smaller in summer and early fall, the multidecadal variations seen in these seasons are also important, as shown later in Fig. 8.

To better understand the mechanisms at the origin of the multidecadal hydroclimate variations in the Seine basin, a composite analysis between the negative multidecadal phases, which correspond to the drier-than-average periods identified from the Seine river flows at Poses after lowfrequency filtering (Fig. 7), and positive multidecadal phases, which correspond to the wetter-than-average periods, is conducted for the main hydrological variables (Fig. 8). The negative phases are defined as the periods 1885-1905 and 19401960 , and the positive phases are defined as the periods 1910-1930 and 1975-1995. The use of four 20-year periods thanks to the length of the reconstruction makes the analysis of these variations more robust in comparison to previous works (e.g., Boé and Habets, 2014; Bonnet et al., 2017). A Student's $t$ test with a $p$ value $<0.05$ is applied to evaluate the significance of changes between the negative and positive multidecadal phases.

Strong river flow variations between the negative and positive multidecadal phases are seen at most simulated stations (Fig. 8a, e, i and $\mathrm{m}$ ). The relative differences are stronger in spring and summer, as large as $40 \%$ for some stations, and significant almost everywhere.

In spring, the river flow anomalies are concomitant with strong and significant precipitation anomalies over the en- tire Seine basin (Fig. 8f). During the negative multidecadal phases, spring precipitation is on average $20 \%$ lower than during the positive phases. These precipitation anomalies also lead to significant soil moisture anomalies, between 5 and $10 \%$ (Fig. 8g). The evapotranspiration in spring does not show significant differences between the negative and positive multidecadal phases of the Seine river flows (Fig. 8h), likely because evapotranspiration is energy-limited rather than water-limited in this region in spring.

In summer, unlike in spring, no significant differences in precipitation between positive and negative multidecadal phases are noted (Fig. 8j). The significant summer river flow variations therefore cannot be explained by concomitant precipitation variations alone, suggesting that hydrological processes are at play. Large soil moisture anomalies, significant over a large part of the catchment, are noted in summer between positive and negative multidecadal phases (between 10 and $15 \%$, Fig. 8k). The absence of significant precipitation and evapotranspiration anomalies in summer suggests that the persistence of soil moisture anomalies from spring to summer (e.g., Boé and Habets, 2014) is responsible for the multidecadal variations of summer soil moisture.

In winter, the relative variations in river flows between the positive and negative multidecadal phases are weaker than in spring and summer, but they are still significant for most of the stations. Slight differences in precipitation, between 5 and $10 \%$ on average over the Seine basin, are noted, but they are not significant. The variations in precipitation alone therefore likely cannot explain such river flow variations in winter. The negative multidecadal phases of the Seine river flows are characterized by significantly lower evapotranspiration anomalies (Fig. 8d). Negative temperature anomalies, close to $-0.8 \mathrm{~K}$ and significant over the whole basin (not shown), are likely the cause of these evapotranspiration anomalies. As the evapotranspiration anomalies are negative during the dry phases, they are not responsible for the river flow anomalies and actually tend to mitigate them. The soil moisture presents significant variations between the negative and positive phases over a part of the Seine basin in winter (between 5 and $10 \%$ ) (Fig. 8c). They are probably related to the differences in precipitation previously noted, even if they are not significant. In fall, only a few stations show significant differences in river flows between the positive and negative multidecadal phases, although some stations, mainly in the southeast of the catchment, still show strong variations of $30 \%$ (Fig. 8m). A part of these anomalies are likely driven by the concomitant variations in precipitation, significant over a small area in the southeast of the catchment (Fig. 8n).

Two important conclusions arise from the previous analysis. (i) Significant multidecadal variations in soil moisture exist in spring and summer from the mid-19th century, with potentially important societal consequences, for example regarding agriculture, which is highly developed over the Seine catchment. (ii) Large and significant multidecadal variations in summer and winter river flows exist, which cannot be ex- 


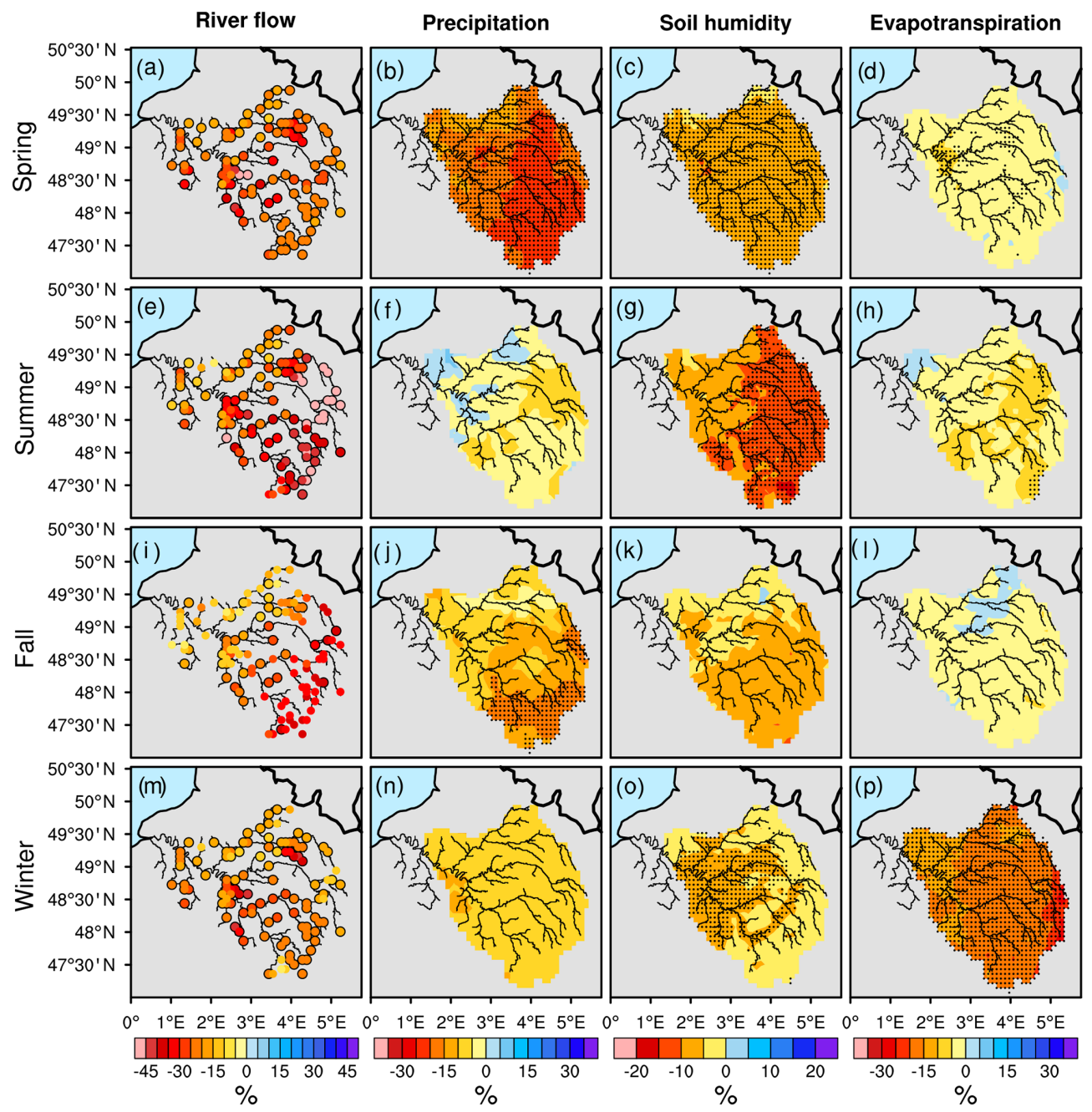

Figure 8. Relative differences (\%) in detrended (a, e, i, m) simulated river flows, (b, f, j, n) precipitation, (c, $\mathbf{g}, \mathbf{k}, \mathbf{o})$ soil wetness index (SWI) and (d, h, l, p) evapotranspiration, between the negative multidecadal phases of the Seine river flows (1885-1905 and 1940-1960) and the positive phases (1910-1930 and 1975-1995). The reference is calculated as the average of these four periods. (a-d) Winter, (e-h) spring, (i-l) summer and (m-p) autumn. Simulated river flows, precipitation, SWI and evapotranspiration come from the Seine reconstruction. Black circles and dots show where the differences are significant based on a Student's $t$ test with a $p$ value $<0.05$.

plained by concomitant variations in precipitation. Hydrological mechanisms that could be responsible for these variations are now investigated.

\subsection{Role of groundwater table}

In the Seine basin, the groundwater-river exchanges play an important role in sustaining summer flows (Rousset et al., 2004). The groundwater-river exchanges from the reconstruction, calculated by the Aqui-FR hydrogeological model, show strong multidecadal variations over the past 150 years for all seasons (Fig. 9). These variations are in phase with the multidecadal variations in river flows noted previously, and their amplitude is large (compare Figs. 7 and 9), pointing to an important role of groundwater dynamics in modulating multidecadal river flows. We calculated the standard deviation of filtered river flows series (as shown in Fig. 7) before and after the subtraction of groundwater-river exchanges shown in Fig. 9. The standard deviation is $64 \%$ lower in summer, $52 \%$ lower in autumn, $41 \%$ lower in spring and $38 \%$ lower in winter after the subtraction of the contribution of groundwater to river flows. Groundwater-river exchanges are therefore the dominant driver of multidecadal variations in summer and autumn river flows, with an important influence in winter and spring as well. The multidecadal variations in groundwater levels are very likely due to variations in the recharge explained by the multidecadal variations noted previously in spring precipitation, especially in early spring, a period favorable to the recharge. 


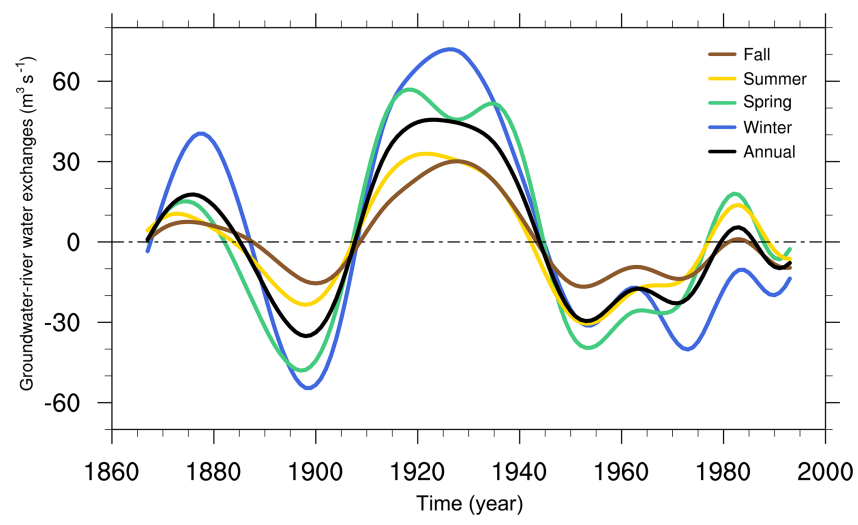

Figure 9. Annual low-pass-filtered anomalies of the (black) annual, (blue) winter, (green) spring, (yellow) summer and (brown) fall average groundwater-river water exchanges over the Seine basin in the reconstruction. The reference period is $1852-2008$.

\subsection{Role of soil moisture}

As variations in groundwater-river exchanges, very likely induced by spring precipitation, roughly explain two-thirds of the strong multidecadal river flow variations that exist in summer, other mechanisms are involved. As seen in Fig. 8k, a large part of the basin in summer is characterized by significant negative soil moisture anomalies during negative multidecadal river flow phases, according to a Student's $t$ test with a $p$ value $<0.05$. Soil moisture anomalies may impact river flows through the modulation of the partitioning of precipitation between runoff and infiltration (e.g., Boé and Habets, 2014), as higher soil moisture may favor runoff over infiltration. To assess whether soil moisture may play a role in summer river flow variations, the relative changes in the ratio of total runoff to precipitation between the positive and negative multidecadal phases is calculated in summer with the reconstruction (Fig. 10). During the dry multidecadal phases, the ratio between total runoff and precipitation in summer is significantly lower over a large part of the basin, where the soil moisture anomalies are significant (Fig. 10). As suggested by Bonnet et al. (2017) for the Loire Basin (see Fig. 1), positive multidecadal anomalies in spring soil moisture due to anomalous precipitation persist in summer, especially over the upstream part of the catchment, and then influence summer river flows by favoring runoff against infiltration.

\section{Role of large-scale circulation and influence of ocean variability}

Strong multidecadal hydroclimate variations in the Seine basin from the 1850s have been highlighted in the previous section. They are mainly linked to variations in precipitation in spring and, to a lesser extent, in fall and winter. The question is now, therefore, to understand the origin of these precipitation variations. The role of large-scale at-

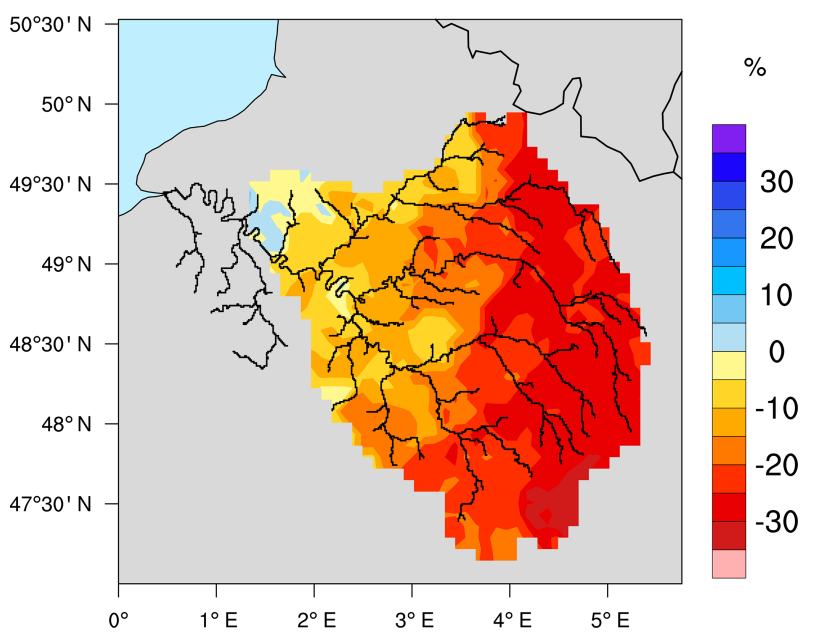

Figure 10. Relative differences $(\%)$ in the ratio between the total runoff and precipitation of the reconstruction, calculated in summer between the negative multidecadal phases of the Seine river flows (1885-1905 and 1940-1960) and the positive phases (19101930 and 1975-1995). The reference for the calculation of the relative anomalies is the average of these four periods. Dots show where the differences are significant based on a Student's $t$ test $(p$ value $<0.05)$.

mospheric circulation, an important driver of precipitation, is first studied. A composite analysis of sea level pressure during the positive and negative multidecadal phases of the Seine river flows previously defined is conducted. As in Sect. 5.1, the significance of changes between negative and positive multi-decadal phases is assessed with a Student's $t$ test and a $p$ value $<0.05$.

Sea level pressure shows significant differences between the positive and negative hydroclimate phases identified in Sect. 5.1 (Fig. 11a). The negative multidecadal phases of the Seine river flows are characterized by significantly higher pressures over northern Europe and significantly lower pressures over North Africa. This circulation pattern leads to weaker westerlies over western Europe and therefore to negative precipitation anomalies over the Seine basin. This dipole pattern of sea level pressure bears resemblance to the NAO, but with a slight shift to the south.

Due to its chaotic nature, the existence of significant atmospheric circulation anomalies for a few decades suggests the existence of a slow external forcing acting on the atmosphere. Because of its inertia, the ocean could be involved. Significant variations of sea surface temperature in the North Atlantic are visible between the multidecadal phases of the Seine river flows. During the negative phases, the North Atlantic basin is characterized by warmer surface temperatures relative to the positive phases, around 0.4 to $0.7^{\circ} \mathrm{C}$, especially in the subpolar gyre and the tropical North Atlantic (Fig. 11b). These SST anomalies in the North Atlantic are reminiscent of those associated with the AMV, the main mode of multidecadal variability in the North At- 

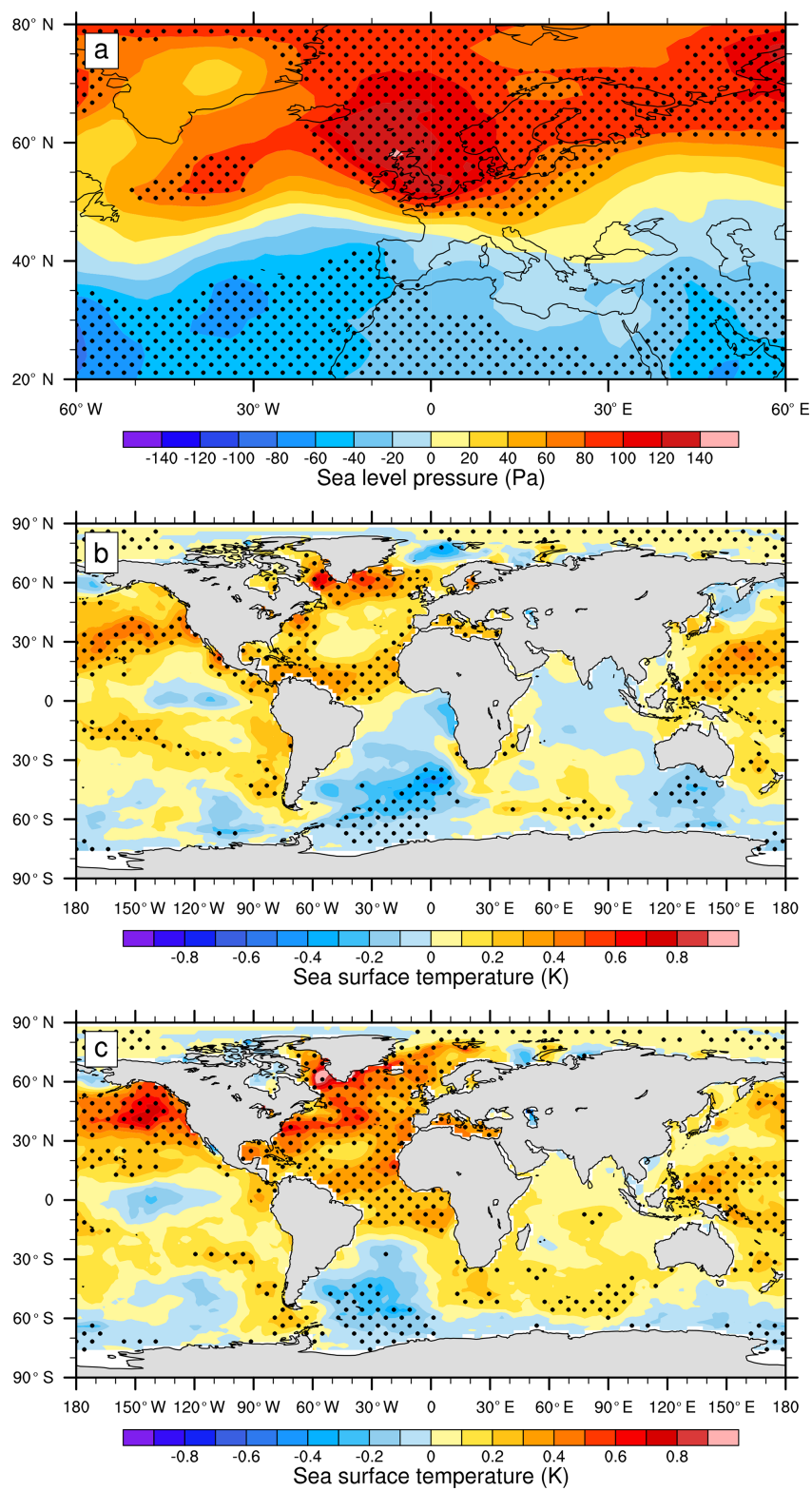

Figure 11. Differences in (a) detrended pressure at sea level (SLP) (Pa) and (b) detrended sea surface temperature (SST) (K) between the negative multidecadal phases of the Seine river flows (18851905 and 1940-1960) and the positive phases (1910-1930 and 1975-1995). (c) Same as panel (b) with a lag of 10 years (SSTs lead by 10 years). SLP comes from the NOAA 20CRv2c reanalysis. SST comes from ERSSTv5 (Huang et al., 2017). The trends are calculated with the EEMD method and subtracted at each grid point. Dots indicate where the differences are significant based on a Student's $t$ test with a $p$ value $<0.05$.

lantic/Europe region. Our results are therefore consistent with Sutton and Dong (2012), who suggested, based on an observational analysis, that the AMV is associated with negative precipitation anomalies over France in spring, the season during which the decadal precipitation anomalies are the largest (Fig. 8f), through a modulation of large-scale atmospheric circulation. Boé and Habets (2014) came to a similar conclusion but suggested the existence of a lag between the AMV and river flow anomalies, with the AMV leading by several years. Interestingly, considering a 10-year time lag in the composite analysis (with the SST leading), SST anomalies in the North Atlantic are much higher than with no lag (Fig. 11c).

Significant SST anomalies between the negative and positive multidecadal phases of the Seine river flows are also observed in the North Pacific. SSTs there are significantly warmer during the negative multidecadal phases of Seine river flows compared to the positive phases. The potential mechanisms linking the SST anomalies in the North Pacific and multidecadal hydroclimate variations over France are not clear. Ding et al. (2017) suggest that the Pacific Decadal Variability (PDV) (Mantua and Hare, 2002) combined with La Niña events could result in precipitation and temperature anomalies over Europe by favoring NAO-like circulation patterns. The phase of the NAO and therefore the sign of precipitation and temperature anomalies is dependent on the type of La Niña. Note also that the apparent link between the North Pacific SSTs and Seine river flows might not be causal. SST anomalies in the North Pacific might be to a certain extent also driven by the AMV. Ruprich-Robert et al. (2017) indeed suggest that the AMV may influence North Pacific SSTs, mainly through an atmospheric connection.

In order to further investigate the relationship between the AMV and the multidecadal hydroclimate variations over the Seine basin, the lagged correlations between the AMV index and spring river flows and precipitation series are computed (Fig. 12). The AMV index is defined as the low-pass-filtered average of the North Atlantic SSTs, from which the forced signal has been removed (Deser et al., 2010). Here, the forced signal is estimated with the trend calculated with the EEMD method (see Sect. 2.4). A "phase-scrambled bootstrapping test" with a $p$ value $<0.05$ is used to assess the significance of the correlation (Davison and Hinkley, 1997). Significant anticorrelations (around -0.8 and -0.9 ) are found between the AMV index calculated with the SSTs from the 20CRv2c reanalysis and low-frequency-filtered spring precipitation over the Seine catchment, with a lag of about 10 years, consistent with the lag found by Boé and Habets (2014) (Fig. 12a). Similar results are obtained using the AMV index from Wang et al. (2017). This paleoclimate reconstruction, based on multiple proxies, is largely independent of the first AMV index. Given the length of the paleoclimate AMV index of Wang et al. (2017) and the availability of a very long observed series of precipitation at Paris (Sect. 2), it is possible to investigate the temporal stability of the AMV/spring precipitation relationship. Similar results are obtained for the periods 1779-1889 and 1890-1990 (Fig. 12a), highlighting the robustness of the relationship.

The influence of the AMV on spring precipitation is reflected for spring river flows. Significant anticorrelations are 

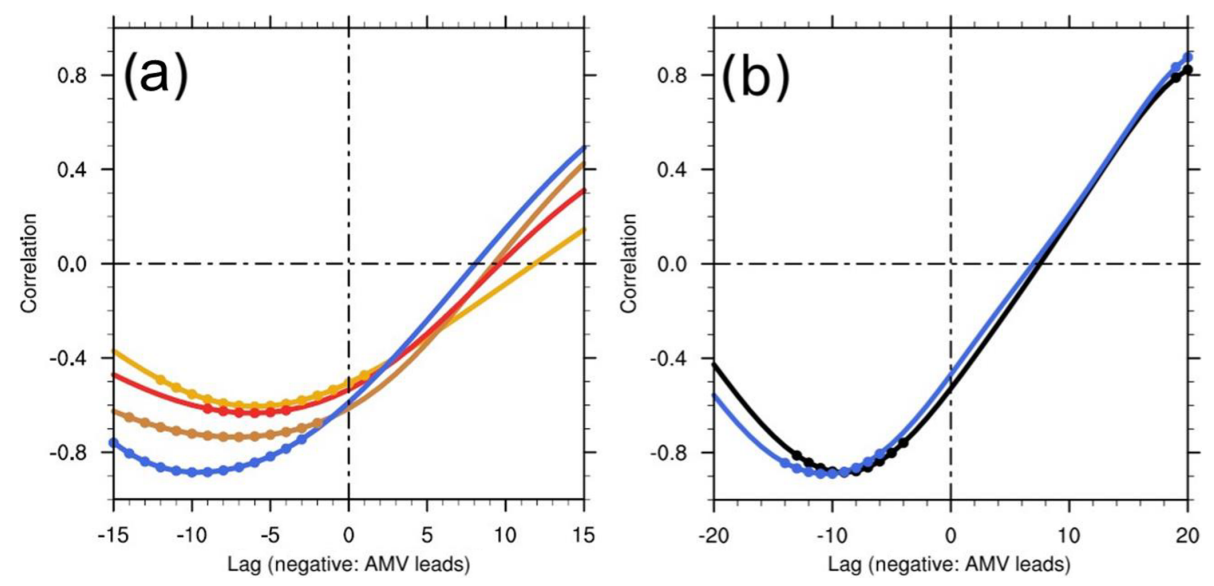

Figure 12. (a) Lagged correlations (lag in year, negative values: AMV leads) between the paleoclimate AMV index of Wang et al. (2017) and the long series of spring precipitation observed at Paris (Slonosky, 2002) over the period 1780-1889 (yellow), 1890-1989 (brown) and 1779-1989 (red). In blue, the correlations between the AMV index calculated from the 20CRv2c reanalysis and the spring precipitation from the reconstruction over the period 1882-1979. (b) Lagged correlations (lag in year) between the AMV index calculated from the 20CRv2c reanalysis and the spring river flows from (blue) the reconstruction at Paris and (black) the observations at Paris Austerlitz over the period 1882-1979. The trends in SST, precipitation and river flows series are calculated with the EEMD algorithm and subtracted from the original series before the calculation of the correlations. The series are filtered with a Lanczos filter with a 21-year window. The points represent significant correlations with a $p$ value $<0.05$ (at least $95 \%$ of the null hypothesis is rejected) according to the "phase-scrambled bootstrapping test" (Davison and Hinkley, 1997).

found between the AMV and the river flows of the Seine at Paris at multidecadal timescales for the period 1876-1985, with a lag of about 10 years, as for precipitation (Fig. 12b). The results obtained with the observations and the reconstruction are very similar.

The 20th century is a very short period upon which to base characterization of multidecadal climate variations. In such a short period, the sampling uncertainties are very large, which may question the robustness of the results (Qasmi et al., 2017). Additionally, non-stationarities may exist (Cassou et al., 2018), and the strong influence of anthropogenic forcings on the climate of the second half of the 20th century may complicate the interpretation of observed multidecadal variations. The results previously described are therefore important because they confirm those obtained in previous works, but over a considerably longer period, at least from the end of the 18th century. They show the robustness of the teleconnection between the AMV and spring precipitation over France described in Sutton and Dong (2012) and confirm the existence of the lag suggested in Boé and Habets (2014), even if its physical origin is still unknown. These results also confirm that the multidecadal hydroclimate variations observed over France are likely not mainly the result of anthropogenic forcings.

\section{Influence of multidecadal river flow variations on high and low flows}

\subsection{Links with high and low flows}

The improvements to the reconstruction described in Sect. 3 allow for a better representation of high-frequency variations compared to previous works (Bonnet et al., 2017; see Fig. 3) and therefore of low and high flows. To assess the influence of multidecadal hydroclimate variations on high and low flows, the ratios of the number of high- and low-flow days during the positive and negative multidecadal phases of the Seine river flows are calculated (Fig. 13). A high-flow day is simply defined here as a day with flows larger than the 95th percentile computed for the four multidecadal phases considered (1910-1930, 1975-1995, 1885-1905 and 19401960) for the flood season, from November to April. Conversely, low-flow days are defined as days with flows lower than the 5th percentile in the same periods but considering all months of the year.

Days with high flows are on average twice as likely to occur during a positive multidecadal phase of the Seine river flows, and up to 3 times more likely for some stations (Fig. 13a). During the flood season, the positive multidecadal phases of the Seine river flows are characterized by higher mean precipitation, wetter soils (Fig. 8) and higher groundwater levels (not shown). Such anomalies favor the occurrence of high flows. The positive multidecadal phases are also characterized by more days with intense precipitation (not shown), which also favors the occurrence of high 


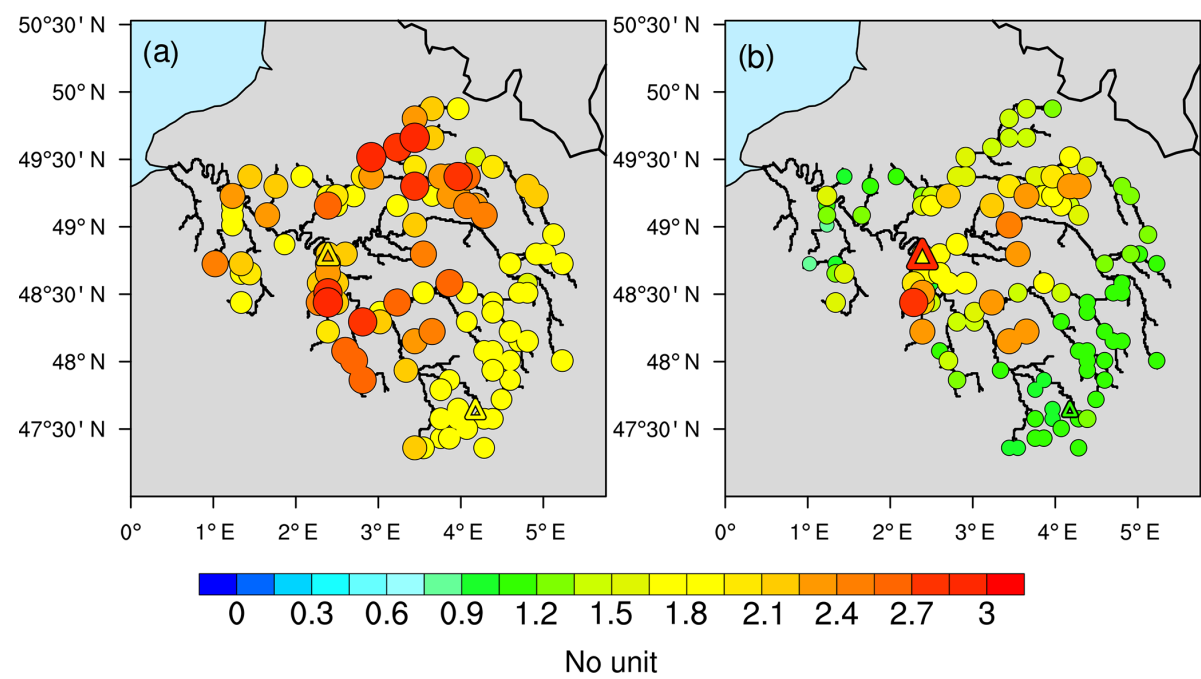

Figure 13. (a) Ratio of the number of days with river flow equal to or greater than the 95th percentile between the positive multidecadal phases of the Seine river flows (1910-1930 and 1975-1995) and the negative phases (1885-1905 and 1940-1960) calculated for the reconstruction (dots), and for the two available long-term observation series (triangles; see Fig. 1). Only the days of the flood season are used (November to April). (b) Same as panel (a) for the days with river flows equal to or lower than the 5th percentile between the negative and the positive multidecadal phases, considering the whole year.

flows. This result is consistent with Willems (2013), who highlighted the existence of multidecadal variations in observed rainfall extremes in Europe, correlated with intense river flows. The results from the reconstruction are consistent with the observations for the two long series available in the Seine basin (Seine at Paris and Armançon at Aisy-surArmançon; see triangles in Fig. 13a).

The multidecadal hydroclimate variability of the Seine basin does not seem to strongly influence daily low flows for many stations. The ratio of low-flow days between negative and positive multidecadal phases is indeed between 1 and 2 for a large number of stations (Fig. 13b). For the observations at Aisy-sur-Armançon (triangle in the southeast of the basin) the ratio is 1.1 , consistent with the reconstruction. For the observations at Paris, days with low flows are more than 4 times more frequent during negative multidecadal phases, whereas they are only twice more frequent in the reconstruction. This discrepancy might be explained by the important influence of human activities on the Seine at Paris. Some stations, notably in the central part of the catchment, show a ratio close to or greater than 2, pointing to an influence of multidecadal hydroclimate variations on low-flow days there. It may be due to the multidecadal variations seen previously in groundwater-river exchanges (Fig. 9), which may impact the daily low flows.

\subsection{The 1921 and 1949 droughts}

To further understand the influence of multidecadal hydroclimate variability on droughts, we focus on two major droughts of the last 150 years: the 1921 and 1949 events. The 1921 drought, characterized as the most severe hydro- logical drought of the Seine basin since the 1850s in our reconstruction (not shown), occurred in the middle of a positive multidecadal phase of the Seine river flows (Fig. 7). The 1949 drought, characterized as the second-longest and thirdstrongest hydrological drought in the Seine basin according to the hydrometeorological reconstruction (not shown), occurred, in contrast, in the middle of a negative multidecadal phase. Droughts are defined as the periods during which the VCN3 index ( $3 \mathrm{~d}$ moving average minimum flow) remains inferior to the 5-year return value. The severity of a drought is defined as the relative difference between the VCN3 index averaged over a given drought and the average value of the index for all droughts.

Considering the 20-year periods centered on these events, the mean climate conditions during which these events developed are therefore very different. Climatological groundwater levels are very high in the decades around 1921 compared to the decades around 1949 (Fig. 14d), with therefore larger groundwater-river exchanges (Fig. 14c). The same applies to river flows (Fig. 14b).

For both droughts, precipitation is below the climatological average from the autumn of the previous year (i.e., $n-1$ ) and extremely small in February, March and April of the year $n$. Between October of year $n-1$ and December of year $n$, average precipitation is lower in 1921 than in 1949 (1.25 and $1.50 \mathrm{~mm} \mathrm{~d}^{-1}$, respectively, well below the climatological average in both cases). The groundwater levels in autumn 1920 are very high, partly because of the multidecadal variations previously described, while the heads are already below average in autumn 1948. In both cases, the levels fall during the drought, but they remain not extreme in 1921, 

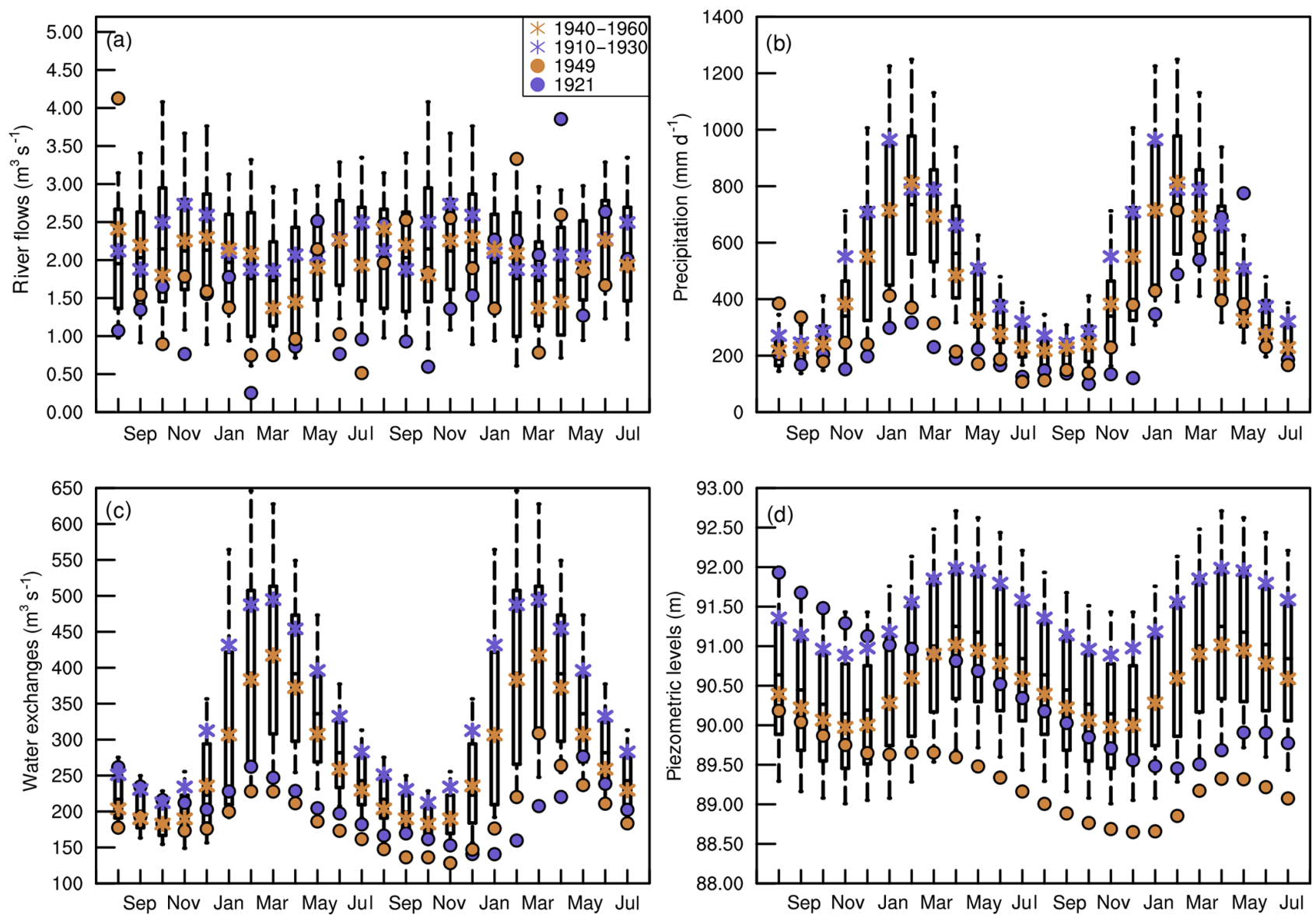

Figure 14. (a) Evolution of monthly precipitation $\left(\mathrm{mmd}^{-1}\right.$ ) averaged over the Seine basin from August 1920 to July 1922 (purple dots) and from August 1948 to July 1950 (beige dots). The boxplots represent the climatological monthly distributions calculated over the period 1852-2008. Purple (beige) crosses show the monthly average over the period 1910-1930 (1940-1960). (b) Same as panel (a) for river flows at Poses $\left(\mathrm{m}^{3} \mathrm{~s}^{-1}\right)$, (c) water exchanges between groundwater and rivers $\left(\mathrm{m}^{3} \mathrm{~s}^{-1}\right)$ and (d) the piezometric levels $(\mathrm{m})$ of the unconfined part of the aquifer. The data come from the Seine reconstruction. The boxplots are defined with the 10th percentile, 25th percentile, median, 75 th percentile and 90th percentile.

while exceptionally low values are reached in spring 1949. As a result, the groundwater to river exchanges in 1921 remain above those of 1949 by between 17 and $83 \mathrm{~m}^{3} \mathrm{~s}^{-1}$ from August of year $n-1$ to September of year $n$ (Fig. 14c-d). Despite the lower groundwater-river exchanges, the rivers flows of the 1949 event generally remain above those of the 1921 drought from the autumn of year $n-1$ to the spring of year $n$. The larger groundwater-river exchanges in 1921 contributed to mitigating the severity of the 1921 hydrological drought, while in 1949 the lower climatological groundwater levels contributed to increasing the severity of the drought. The already exceptional 1921 drought could have been even worse had it occurred during a dry multidecadal phase as for the 1949 event.

\section{Discussion}

In this study, a new hydrometeorological reconstruction focusing on the Seine basin is presented. The method improves upon the one described in Bonnet et al. (2017). It leads to a better representation of daily river flows. This reconstruction is therefore suitable for studying the multidecadal variability of high and low flows, as well as hydrological extremes. The reconstruction is extended back to the middle of the 19th century. The longer study period compared to previous works (e.g., Boé and Habets, 2014) allows for a more robust characterization of multidecadal hydrological variations, which is crucial in that context (e.g., Cassou et al., 2018).

Although the reconstruction developed in this study is a useful tool for studying the past variability of the hydrological cycle over the Seine basin, it is obviously not perfect. Uncertainties are present throughout the modeling chain. The 
statistical downscaling method used at the first step of the reconstruction method assumes that the learning period, over which the large-scale reanalysis and the SAFRAN analysis overlap (1959-2010), is representative of the meteorological conditions of the period 1851-2010. The consistent performances of the reconstruction over the entire period shown by several analyses in this study suggest that this hypothesis has no major impact on our results. Important uncertainties are associated with the $20 \mathrm{CRv} 2 \mathrm{c}$ reanalysis at the beginning of the period, due to the smaller number of assimilated observations (Krueger et al., 2013). We use monthly homogenized local precipitation and temperature observations to constrain the results of statistical downscaling in order to improve the temporal homogeneity of the reconstruction, but the homogenization method is quite old and does not benefit from recent advances in homogenization procedures. The good agreement between the low-frequency variations of the homogenized monthly precipitation series and those of the Global Precipitation Climatology Centre data set (Schneider et al., 2008) from 1901 to 2011 (not shown) still gives good confidence in the overall realism of the multidecadal variations described in this study.

The hydrological model used in this work is also not perfect, with potential consequences on our results. The amplitude of the variations in the piezometric levels at Toury in particular is strongly underestimated. Although this is a one-point measurement, it is possible that this underestimation exists for the entire Beauce aquifer, which could imply an underestimation of the multidecadal variability of reconstructed river flows, especially in summer, when the role of groundwater is particularly important. This underestimation is likely due to hydrological modeling and could come from a too-simple representation of the limestone aquifer that neglects some confined parts. The river channel dimensions and conveyance capacity are also supposed constant over time, whereas they could be affected by multidecadal climate variability (Slater et al., 2019).

Some important uncertainties are also associated with the observations used for the evaluation of the reconstruction. They may indeed be influenced by non-climatic anthropogenic influences such as dams and pumping, not taken into account in the hydrological model, or changes in measurement methods for example. We have evaluated the reconstruction against multiple observations in an effort to ensure that our results are not too dependent on a particular source of information and to better understand the potential limitations of the reconstruction.

Even if it is not the object of this study, an important difference of long-term trends in river flows exists between the reconstruction and the observations for the Seine at Paris. The origin of these differences is not understood currently. The meteorological variables used as forcing for the reconstruction, and precipitation in particular, do not show unrealistic trends (not shown), and therefore the trends in reconstructed river flows may not be unrealistic. As the Seine basin is heavily impacted by human activities, it is possible that non-climatic anthropogenic influences, which are not taken into account in the reconstruction, are responsible for the large negative trend in the observed series. It is something worth investigating in future work.

\section{Conclusions and perspectives}

Based on the reconstruction developed in this study, we show the existence of strong multidecadal variations in river flows over the Seine catchment since the 1850s. Consistent with previous studies over France (Boé and Habets, 2014; Bonnet et al., 2017), strong variations are noted in spring. For many stations, even stronger variations are noted in summer. Significant multidecadal variations are also noted in winter thanks to the longer period studied here. Spring precipitation directly impacts not only river flows in spring but also river flows in the other seasons through different hydrological processes. Spring precipitation leads to soil moisture anomalies in spring that persist until summer, regulating the runoff-to-precipitation ratio. Precipitation variations in early spring impact groundwater recharge and then river flows during all seasons through groundwater-river exchanges. The multidecadal variations in both soil moisture and groundwater may have important direct societal impacts, independently of their impacts of river flows, in particular with regards to agriculture. Interestingly, the variations in summer river flows are much larger than seen in Bonnet et al. (2017). These differences are likely due both to the longer period studied here and to different hydrogeological models, with a finer representation of aquifers in the present study.

The multidecadal hydroclimate variations over the Seine basin are due to large-scale atmospheric circulation anomalies, themselves associated with sea surface temperature anomalies in the North Atlantic. Interestingly, a potential connection to the North Pacific, not described before, is also noted.

As discussed by Cassou et al. (2018), because of major sampling uncertainties and potential non-stationarities, it is important to extend the analyses of multidecadal climate variations as far back in time as possible, in order to confirm or deny the results obtained by most studies on the 20th century. Our results confirm the link between the AMV and French hydroclimate variations seen in previous studies based on shorter periods, pointing to their robustness. The fact that multidecadal hydroclimate variations exist before the 20th century, a period where the role of anthropogenic forcings is small, also reinforces the idea that they are of internal origin to a large extent and not primarily forced by greenhouse gases or sulfate aerosols.

An interesting new result is that the multidecadal variations previously described for the mean hydroclimate may also influence high and low flows. The positive multidecadal phases seem to be more conducive to flooding. Over large 
parts of the catchment the probability of high flows is more than doubled during wet multidecadal phases. Although these events are mainly the result of specific weather conditions, the mean state of the hydrological system (e.g., soil moisture or groundwater), influenced by the multidecadal hydroclimate variations, may amplify or reduce the magnitude of these events. The impact of multidecadal variations in low flows is more regional. Still, we have illustrated for two major droughts of the 20th century, in 1921 and 1949, how multidecadal hydroclimate variations, through their impact on groundwater, may modulate the intensity of droughts. Multidecadal variations in groundwater may have reduced the intensity of the 1921 drought and increased the intensity of the 1949 drought.

The results described in this paper illustrate that relying on short periods of a few decades (e.g., three) to characterize hydrological hazards can be problematic, especially for practical purposes. Indeed, with such short periods, the existence of multidecadal hydrological variations may make the estimation of flood characteristics or of the probability of the occurrence of droughts, for example, unreliable.

This study reinforces the idea that the hydroclimate variability over the Seine basin and more generally over France results from a teleconnection with North Atlantic SSTs, and suggests a potential role of North Pacific SSTs. The associated mechanisms are still poorly understood. The Decadal Climate Prediction Project (Boer et al., 2016) of the Coupled Model Intercomparison Project Phase 6 (Eyring et al., 2016) proposes some dedicated numerical experiments to tackle these questions. They will hopefully allow some progress in our understanding of the physical origin of multidecadal hydrological variations over France.

Given the large multidecadal hydroclimate variations described in this study, it is crucial to assess whether climate models reproduce them correctly and therefore if the uncertainties due to internal variability are correctly captured in current projections. It may not be the case. For example, Qasmi et al. (2017) show that climate models may have difficulties capturing some properties of the AMV. Simpson et al. (2018) suggest that current climate models underestimate the multidecadal variations of the atmospheric jet over the North Atlantic in late winter/early spring, which would have consequences for the French hydroclimate. Understanding the potential consequences of these issues regarding the uncertainties in hydroclimate projections is now crucial.

Data availability. Twentieth Century Reanalysis data are provided by the NOAA Earth System Research Laboratory's Physical Sciences Division (PSD), Boulder, Colorado, USA, from their website: https://www.esrl.noaa.gov/psd/data/gridded/ data.20thC_ReanV2c.html (Compo et al., 2011). The river flow observations, from the national HYDRO database, are available at http://hydro.eaufrance.fr/selection.php?consulte=rechercher (Central Service for Hydrometeorology and Flood Forecasting Sup- port, 2020). Data from the hydro-meteorological reconstruction developed in this study are available from the authors upon reasonable request.

Author contributions. All authors framed the study and contributed to the interpretation of the results and to the writing of the paper. RB and JB designed the reconstruction methodology. FH ran the AquiFR model with the reconstructed meteorological forcing developed by RB. RB performed the analyses.

Competing interests. The authors declare that they have no conflict of interest.

Acknowledgements. This work has been supported by the French National program LEFE/INSU through the VITESSE project. The figures have been produced using the NCAR Command Language (National Center for Atmospheris Research, 2016). The authors acknowledge all the colleagues from Météo-France and MinesParisTech who have been contributing to the development of the SAFRAN-SURFEX system, as well as Aqui-FR, and Météo France (direction de la climatologie et des services climatiques) for providing the precipitation and temperature data sets. We also want to thank Thierry Morel from Cerfacs, heavily involved in the AquiFR project. The authors also thank Laurence Lestel, involved in the VITESSE project, for useful discussions about this work. Support for the Twentieth Century Reanalysis Project data set is provided by the U.S. Department of Energy's (Office of Science) Innovative and Novel Computational Impact on Theory and Experiment (DOE INCITE) program and Biological and Environmental Research (BER) program, and by the National Oceanic and Atmospheric Administration Climate Program Office.

Financial support. This research has been supported by the LEFE/INSU (grant no. AO LEFE 2016: VITESSE).

Review statement. This paper was edited by Niko Wanders and reviewed by three anonymous referees.

\section{References}

Bindoff, N. L., Stott, P. A., AchutaRao, K. M., Allen, M. R., Gillett, N., Gutzler, D., Hansingo, K., Hegerl, G., Hu, Y., Jain, S., Mokhov, I. I., Overland, J., Perlwitz, J., Sebbari, R., and Zhang, X.: Detection and attribution of climate change: from global to regional, Climate Change 2013: The Physical Science Basis, Contribution of Working Group I to the Fifth Assessment Report of the Intergovernmental Panel on Climate Change, edited by: Stocker, T. F., Qin, D., Plattner, G.-K., Tignor, M., Allen, S. K., Boschung, J., Nauels, A., Xia, Y., Bex, V., and Midgley, P. M., Cambridge University Press, Cambridge, UK and New York, NY, USA, 2013. 
Boé, J.: Modulation of the summer hydrological cycle evolution over western Europe by anthropogenic aerosols and soilatmosphere interactions, Geophys. Res. Lett., 43, 7678-7685, 2016.

Boé, J. and Habets, F.: Multi-decadal river flow variations in France, Hydrol. Earth Syst. Sci., 18, 691-708, https://doi.org/10.5194/hess-18-691-2014, 2014.

Boer, G. J., Smith, D. M., Cassou, C., Doblas-Reyes, F., Danabasoglu, G., Kirtman, B., Kushnir, Y., Kimoto, M., Meehl, G. A., Msadek, R., Mueller, W. A., Taylor, K. E., Zwiers, F., Rixen, M., Ruprich-Robert, Y., and Eade, R.: The Decadal Climate Prediction Project (DCPP) contribution to CMIP6, Geosci. Model Dev., 9, 3751-3777, https://doi.org/10.5194/gmd-9-3751-2016, 2016.

Bonnet, R., Boé, J., Dayon, G., and Martin, E.: Twentieth-Century Hydrometeorological Reconstructions to Study the Multidecadal Variations of the Water Cycle Over France, Water Resour. Res., 53, 8366-8382, 2017.

Bouwer, L. M., Vermaat, J. E., and Aerts, J. C.: Regional sensitivities of mean and peak river discharge to climate variability in Europe, J. Geophys. Res.-Atmos., 113, D19103, https://doi.org/10.1029/2008JD010301, 2008.

Caillouet, L., Vidal, J.-P., Sauquet, E., and Graff, B.: Probabilistic precipitation and temperature downscaling of the Twentieth Century Reanalysis over France, Clim. Past, 12, 635-662, https://doi.org/10.5194/cp-12-635-2016, 2016.

Casanueva, A., Rodríguez-Puebla, C., Frías, M. D., and GonzálezReviriego, N.: Variability of extreme precipitation over Europe and its relationships with teleconnection patterns, Hydrol. Earth Syst. Sci., 18, 709-725, https://doi.org/10.5194/hess-18709-2014, 2014.

Cassou, C., Terray, L., Hurrell, J. W., and Deser, C.: North Atlantic winter climate regimes: Spatial asymmetry, stationarity with time, and oceanic forcing, J. Climate, 17, 1055-1068, 2004.

Cassou, C., Kushnir, Y., Hawkins, E., Pirani, A., Kucharski, F., Kang, I.-S., and Caltabiano, N.: Decadal Climate Variability and Predictability: Challenges and Opportunities, B. Am. Meteorol. Soc., 99, 479-490, 2018.

Central Service for Hydrometeorology and Flood Forecasting Support: River flow observations, Ministry of Ecological Transition and Solidarity, available at: http://hydro.eaufrance.fr/selection. php?consulte=rechercher, last access: 3 April 2020.

Compo, G. P., Whitaker, J. S., Sardeshmukh, P. D., Matsui, N., Allan, R. J., Yin, X., Gleason, B. E., Vose, R. S., Rutledge, G., Bessemoulin, P., Brönnimann, S., Brunet, M., Crouthamel, R. I., Grant, A. N., Groisman, P. Y., Jones, P. D., Kruk, M. C., Kruger, A. C., Marshall, G. J., Maugeri, M., Mok, H. Y., Nordli, Ø., Ross, T. F., Trigo, R. M., Wang, X. L., Woodruff, S. D., and Worley, S. J.: The twentieth century reanalysis project, Q. J. Roy. Meteor. Soc., 137, 1-28, https://doi.org/10.1002/qj.776, 2011 (data available at: https://www.esrl.noaa.gov/psd/data/gridded/data.20thC_ ReanV2c.html, last access: 3 April 2020).

Davison, A. C. and Hinkley, D. V.: Bootstrap Methods and their Application, vol. 1, Cambridge University Press, Cambridge, UK, 1997.

Dayon, G., Boé, J., Martin, É., and Gailhard, J.: Impacts of climate change on the hydrological cycle over France and associated uncertainties, C. R. Geosci., 350, 141-153, https://doi.org/10.1016/j.crte.2018.03.001, 2018.
Decharme, B., Martin, E., and Faroux, S.: Reconciling soil thermal and hydrological lower boundary conditions in land surface models, J. Geophys. Res.-Atmos., 118, 7819-7834, 2013.

Deser, C., Alexander, M. A., Xie, S.-P., and Phillips, A. S.: Sea surface temperature variability: Patterns and mechanisms, Annu. Rev. Mar. Sci., 2, 115-143, 2010.

Deser, C., Phillips, A., Bourdette, V., and Teng, H.: Uncertainty in climate change projections: the role of internal variability, Clim. Dynam., 38, 527-546, 2012.

Dieppois, B., Lawler, D., Slonosky, V., Massei, N., Bigot, S., Fournier, M., and Durand, A.: Multidecadal climate variability over northern France during the past 500 years and its relation to large-scale atmospheric circulation, Int. J. Climatol., 36, 46794696, 2016.

Ding, S., Chen, W., Feng, J., and Graf, H.-F.: Combined impacts of PDO and two types of La Niña on climate anomalies in Europe, J. Climate, 30, 3253-3278, 2017.

Duchon, C. E.: Lanczos filtering in one and two dimensions, J. Appl. Meteorol., 18, 1016-1022, 1979.

Eyring, V., Bony, S., Meehl, G. A., Senior, C. A., Stevens, B., Stouffer, R. J., and Taylor, K. E.: Overview of the Coupled Model Intercomparison Project Phase 6 (CMIP6) experimental design and organization, Geosci. Model Dev., 9, 1937-1958, https://doi.org/10.5194/gmd-9-1937-2016, 2016.

Flipo, N., Monteil, C., Poulin, M., Fouquet, C. d., and Krimissa, M.: Hybrid fitting of a hydrosystem model: Long-term insight into the Beauce aquifer functioning (France), Water Resour. Res., 48, W05509, https://doi.org/10.1029/2011WR011092, 2012.

Giese, B. S., Seidel, H. F., Compo, G. P., and Sardeshmukh, P. D.: An ensemble of ocean reanalyses for 1815-2013 with sparse observational input, J. Geophys. Res.-Oceans, 121, 6891-6910, 2016.

Giuntoli, I., Renard, B., Vidal, J.-P., and Bard, A.: Low flows in France and their relationship to large-scale climate indices, J. Hydrol., 482, 105-118, 2013.

Hawkins, E. and Sutton, R.: The potential to narrow uncertainty in regional climate predictions, B. Am. Meteorol. Soc., 90, 10951108, 2009.

Hingray, B. and Saïd, M.: Partitioning internal variability and model uncertainty components in a multimember multimodel ensemble of climate projections, J. Climate, 27, 6779-6798, 2014.

Hirahara, S., Ishii, M., and Fukuda, Y.: Centennial-scale sea surface temperature analysis and its uncertainty, J. Climate, 30, 16, https://doi.org/10.1175/JCLI-D-12-00837.1, 2017.

Hodgkins, G. A., Whitfield, P. H., Burn, D. H., Hannaford, J., Renard, B., Stahl, K., Fleig, A. K., Madsen, H., Mediero, L., Korhonen, J., Murphy, C., and Wilson, D.: Climate-driven variability in the occurrence of major floods across North America and Europe, J. Hydrol., 552, 704-717, 2017.

Huang, B., Thorne, P. W., Banzon, V. F., Boyer, T., Chepurin, G., Lawrimore, J. H., Menne, M. J., Smith, T. M., Vose, R. S., and Zhang, H.-M.: Extended reconstructed sea surface temperature, version 5 (ERSSTv5): upgrades, validations, and intercomparisons, J. Climate, 30, 8179-8205, 2017.

Hurrell, J. W. and Deser, C.: North Atlantic climate variability: the role of the North Atlantic Oscillation, J. Marine Syst., 78, 28-41, 2009.

Kerr, R. A.: A North Atlantic climate pacemaker for the centuries, Science, 288, 1984-1985, 2000. 
Kingston, D., Lawler, D., and McGregor, G.: Linkages between atmospheric circulation, climate and streamflow in the northern North Atlantic: research prospects, Prog. Phys. Geog., 30, 143174, 2006a.

Kingston, D. G., McGregor, G. R., Hannah, D. M., and Lawler, D. M.: River flow teleconnections across the northern North Atlantic region, Geophys. Res. Lett., 33, L14705, https://doi.org/10.1029/2006GL026574, 2006b.

Krueger, O., Schenk, F., Feser, F., and Weisse, R.: Inconsistencies between long-term trends in storminess derived from the 20CR reanalysis and observations, J. Climate, 26, 868-874, 2013.

Kuentz, A., Mathevet, T., Gailhard, J., and Hingray, B.: Building long-term and high spatio-temporal resolution precipitation and air temperature reanalyses by mixing local observations and global atmospheric reanalyses: the ANATEM model, Hydrol. Earth Syst. Sci., 19, 2717-2736, https://doi.org/10.5194/hess-192717-2015, 2015.

Lorenz, E. N.: Atmospheric predictability as revealed by naturally occurring analogues, J. Atmos. Sci., 26, 636-646, 1969.

Mantua, N. J. and Hare, S. R.: The Pacific decadal oscillation, J. Oceanogr., 58, 35-44, 2002.

Marti, R., Gascoin, S., Houet, T., Ribière, O., Laffly, D., Condom, T., Monnier, S., Schmutz, M., Camerlynck, C., Tihay, J. P., Soubeyroux, J. M., and René, P.: Evolution of Ossoue Glacier (French Pyrenees) since the end of the Little Ice Age, The Cryosphere, 9, 1773-1795, https://doi.org/10.5194/tc-9-17732015, 2015.

Masson, V., Le Moigne, P., Martin, E., Faroux, S., Alias, A., Alkama, R., Belamari, S., Barbu, A., Boone, A., Bouyssel, F., Brousseau, P., Brun, E., Calvet, J.-C., Carrer, D., Decharme, B., Delire, C., Donier, S., Essaouini, K., Gibelin, A.-L., Giordani, H., Habets, F., Jidane, M., Kerdraon, G., Kourzeneva, E., Lafaysse, M., Lafont, S., Lebeaupin Brossier, C., Lemonsu, A., Mahfouf, J.-F., Marguinaud, P., Mokhtari, M., Morin, S., Pigeon, G., Salgado, R., Seity, Y., Taillefer, F., Tanguy, G., Tulet, P., Vincendon, B., Vionnet, V., and Voldoire, A.: The SURFEXv7.2 land and ocean surface platform for coupled or offline simulation of earth surface variables and fluxes, Geosci. Model Dev., 6, 929-960, https://doi.org/10.5194/gmd-6-929-2013, 2013.

Minvielle, M., Pagé, C., Céron, J.-P., and Besson, F.: Extension of the SIM reanalysis by combination of observations and statistical downscaling, in: Engineering Geology for Society and Territory - Volume 1, Springer, Cham, Switzerland, 189-192, 2015.

Moisselin, J.-M. and Dubuisson, B.: Évolution des valeurs extrêmes de température et de précipitations au cours du XXe siècle en France, La Météorologie, Société météorologique de France, Paris, France, 2006.

Moisselin, J.-M., Schneider, M., and Canellas, C.: Les changements climatiques en France au XXè siècle. Etude des longues séries homogénéisées de données de température et de précipitations, Société météorologique de France, Paris, France, 2002.

National Center for Atmospheris Research: The NCAR Command Language (Version 6.3.0) [Software], UCAR/NCAR/CISL/TDD, Boulder, Colorado, USA, https://doi.org/10.5065/D6WD3XH5, 2016.

Nicolas, J., Verley, F., and Chery, L.: La mesure et la surveillance des niveaux d'eau dans les eaux souterraines: une décennie d'évolutions en France, Géologues, 178, 58-62, 2013.
Noilhan, J. and Planton, S.: A simple parameterization of land surface processes for meteorological models, Mon. Weather Rev., 117, 536-549, 1989.

Obled, C., Bontron, G., and Garçon, R.: Quantitative precipitation forecasts: a statistical adaptation of model outputs through an analogues sorting approach, Atmos. Res., 63, 303-324, 2002.

Oliver, E. C.: Blind use of reanalysis data: apparent trends in Madden-Julian Oscillation activity driven by observational changes, Int. J. Climatol., 36, 3458-3468, 2016.

Pachauri, R. K., Allen, M. R., Barros, V. R., Broome, J., Cramer, W., Christ, R., Church, J. A., Clarke, L., Dahe, Q., Dasgupta, P., Dubash, N. K., Edenhofer, O., Elgizouli, I., Field, C. B., Forster, P., Friedlingstein, P., Fuglestvedt, J., Gomez-Echeverri, L., Hallegatte, S., Hegerl, G., Howden, M., Jiang, K., Jimenez Cisneroz, B., Kattsov, V., Lee, H., Mach, K. J., Marotzke, J., Mastrandrea, M. D., Meyer, L., Minx, J., Mulugetta, Y., O’Brien, K., Oppenheimer, M., Pereira, J. J., Pichs-Madruga, R., Plattner, G. K., Pörtner, H. O., Power, S. B., Preston, B., Ravindranath, N. H., Reisinger, A., Riahi, K., Rusticucci, M., Scholes, R., Seyboth, K., Sokona, Y., Stavins, R., Stocker, T. F., Tschakert, P., van Vuuren, D., and van Ypserle, J. P.: Climate change 2014: synthesis report. Contribution of Working Groups I, II and III to the Fifth assessment report of the Intergovernmental Panel on Climate Change, IPCC, Geneva, Switzerland, 2014.

Philippe, É., Habets, F., Ledoux, E., Goblet, P., Viennot, P., and Mary, B.: Improvement of the solute transfer in a conceptual unsaturated zone scheme: a case study of the Seine River basin, Hydrol. Process., 25, 752-765, 2011.

Qasmi, S., Cassou, C., and Boé, J.: Teleconnection Between Atlantic Multidecadal Variability and European Temperature: Diversity and Evaluation of the Coupled Model Intercomparison Project Phase 5 Models, Geophys. Res. Lett., 44, 11-140, 2017.

Quintana-Segui, P., Le Moigne, P., Durand, Y., Martin, E., Habets, F., Baillon, M., Canellas, C., Franchisteguy, L., and Morel, S.: Analysis of near-surface atmospheric variables: Validation of the SAFRAN analysis over France, J. Appl. Meteorol. Clim., 47, 92 107, 2008.

Rousset, F., Habets, F., Gomez, E., Le Moigne, P., Morel, S., Noilhan, J., and Ledoux, E.: Hydrometeorological modeling of the Seine basin using the SAFRAN-ISBAMODCOU system, J. Geophys. Res.-Atmos., 109, D06113, https://doi.org/10.1029/2003JD004403, 2004.

Ruprich-Robert, Y., Msadek, R., Castruccio, F., Yeager, S., Delworth, T., and Danabasoglu, G.: Assessing the climate impacts of the observed Atlantic multidecadal variability using the GFDL CM2. 1 and NCAR CESM1 global coupled models, J. Climate, 30, 2785-2810, 2017.

Saleh, F., Flipo, N., Habets, F., Ducharne, A., Oudin, L., Viennot, P., and Ledoux, E.: Modeling the impact of in-stream water level fluctuations on stream-aquifer interactions at the regional scale, J. Hydrol., 400, 490-500, 2011.

Schlesinger, M. E. and Ramankutty, N.: An oscillation in the global climate system of period 65-70 years, Nature, 367, 723-726, https://doi.org/10.1038/367723a0, 1994.

Schneider, U., Fuchs, T., Meyer-Christoffer, A., and Rudolf, B.: Global precipitation analysis products of the GPCC, Global Precipitation Climatology Centre (GPCC), DWD, Internet Publikation, 112, 2008. 
Simpson, I. R., Deser, C., McKinnon, K. A., and Barnes, E. A.: Modeled and Observed Multidecadal Variability in the North Atlantic Jet Stream and Its Connection to Sea Surface Temperatures, J. Climate, 31, 8313-8338, 2018.

Slater, L., Khouakhi, A., and Wilby, R.: River channel conveyance capacity adjusts to modes of climate variability, Sci Rep-UK, 9, $1-10,2019$.

Slonosky, V. C.: Wet winters, dry summers? Three centuries of precipitation data from Paris, Geophys. Res. Lett., 29, 34-1, 2002.

Steirou, E., Gerlitz, L., Apel, H., and Merz, B.: Links between largescale circulation patterns and streamflow in Central Europe: A review, J. Hydrol., 549, 484-500, 2017.

Sutton, R. T. and Dong, B.: Atlantic Ocean influence on a shift in European climate in the 1990s, Nat. Geosci., 5, 788-792, https://doi.org/10.1038/ngeo1595, 2012.

Terray, L. and Boé, J.: Quantifying 21st-century France climate change and related uncertainties, C. R. Geosci., 345, 136-149, 2013.

Teweles Jr, S. and Wobus, H. B.: Verification of prognostic charts, B. Am. Meteorol. Soc., 35, 455-463, 1954.

Vergnes, J.-P. and Habets, F.: Impact of river water levels on the simulation of stream-aquifer exchanges over the Upper Rhine alluvial aquifer (France/Germany), Hydrogeol. J., 26, 2443-2457, 2018.

Vergnes, J.-P., Roux, N., Habets, F., Ackerer, P., Amraoui, N., Besson, F., Caballero, Y., Courtois, Q., de Dreuzy, J.-R., Etchevers, P., Gallois, N., Leroux, D. J., Longuevergne, L., Le Moigne, P., Morel, T., Munier, S., Regimbeau, F., Thiéry, D., and Viennot, P.: The AquiFR hydrometeorological modelling platform as a tool for improving groundwater resource monitoring over France: evaluation over a 60-year period, Hydrol. Earth Syst. Sci., 24, 633-654, https://doi.org/10.5194/hess-24633-2020, 2020.
Vidal, J.-P., Martin, E., Franchistéguy, L., Baillon, M., and Soubeyroux, J.-M.: A 50-year high-resolution atmospheric reanalysis over France with the Safran system, Int. J. Climatol., 30, 16271644, 2010.

Viennot, P., Ducharne, A., Habets, F., Lamy, F., and Ledoux, E.: Hydrogéologie du bassin de la Seine, comprendre et anticiper le fonctionnement hydrodynamique du bassin pour une gestion durable de la ressource, Agence de l'eau Seine-Normandie, available at: https://www.piren-seine.fr/sites/default/files/PIREN documents/fascicules/Collection_AESN_PIREN-Seine_02_-_ hydrogeologie.pdf (last access: 2 April 2020), 2009.

Voldoire, A., Sanchez-Gomez, E., y Mélia, D. S., Decharme, B., Cassou, C., Sénési, S., Valcke, S., Beau, I., Alias, A., Chevallier, M., Déqué, M., Deshayes, J., Douville, H., Fernandez, E., Madec, G., Maisonnave, E, Moine, M.-P., Planton, S., SaintMartin, D., Szopa, S., Tyteca, S., Alkama, R., Belamari, S., Braun, A., Coquart, L., and Chauvin, F.: The CNRM-CM5. 1 global climate model: description and basic evaluation, Clim. Dynam., 40, 2091-2121, 2013.

Wang, J., Yang, B., Ljungqvist, F. C., Luterbacher, J., Osborn, T. J., Briffa, K. R., and Zorita, E.: Internal and external forcing of multidecadal Atlantic climate variability over the past 1,200 years, Nat. Geosci., 10, 512, 2017.

Willems, P.: Multidecadal oscillatory behaviour of rainfall extremes in Europe, Climatic Change, 120, 931-944, 2013.

Wu, Z. and Huang, N. E.: Ensemble empirical mode decomposition: a noise-assisted data analysis method, Advances in Adaptive Data Analysis, 1, 1-41, 2009. 